\title{
Fast-Fish, Loose-Fish: \\ How Whalemen, Lawyers, and Judges Created the British Property Law of Whaling
}

\author{
Robert C. Deal ${ }^{*}$
}

Anglo-American whalemen in the eighteenth and nineteenth centuries used customs largely of their own creation to resolve disputes at sea over contested whales. These customs were remarkably effective: litigation was rare and violence even rarer. Legal scholars such as Professor Robert Ellickson have correctly pointed to these customs as an example of how close-knit communities settle disputes without recourse to formal legal institutions or even knowledge of the applicable law. However, Ellickson's belief that these whaling customs were universally followed at sea and were in turn adopted by courts is not entirely accurate. While courts often deferred, in part, to whaling practices, judges and lawyers were also active participants in creating the property law of whaling.

The British whaling cases of the late eighteenth and early nineteenth centuries were part of a discussion dating back to Justinian's Digest about the actions necessary to secure possession and ownership of ferae naturae. British courts at the turn of the nineteenth century did much to advance one whaling custom over a competing practice: several late eighteenth century cases accepted the norm of "fast-fish, loose-fish" as the universal custom of whaling, while the competing practice of "iron holds the whale" was ignored by British courts and was, thereafter, abandoned by whalemen in the Greenland fishery. However, in the 1820s, British lawyers and judges applied the emerging action of interference with trade to whaling disputes, thereby reintroducing aspects of the previously rejected custom of iron holds the whale.

Copyright $(C 2010$ by the Regents of the University of Califomia.

* Ph.D. Temple University, J.D. Villanova University. I would like to thank Robert Gordon, Carol Rose, and all of the participants at the 2009 Law \& Humanities Junior Scholars Workshop for their helpful and encouraging comments on an early version of this Article. I would also like to thank Andrew Isenberg for suggesting whaling as a topic of study and his wise counsel. The editors of Ecology Law Quarterly have been a pleasure to work with and have done much to improve the Article. 


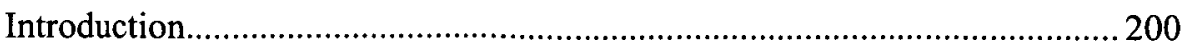

I. The Greenland Whalefishery of the Captains Scoresby .......................204

A. The Challenges of Whaling in Arctic Waters ..............................204

B. An "Equitable System of Regulation" .........................................206

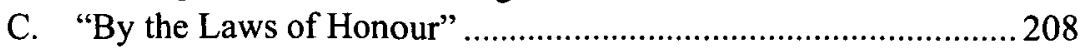

II. English Courts Establish "Fast-Fish, Loose-Fish" as the Law of

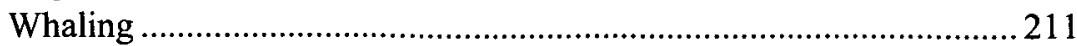

A. Dutch Whaling Customs and Statutes.......................................211

B. The Custom of "Iron Holds the Whale" in the Early Greenland

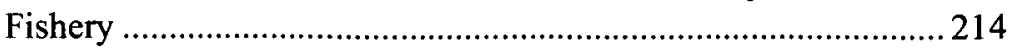

C. Addison v. Row Sounds the Judicially Imposed Death Knoll for Iron Holds the Whale: Different Views of Custom North and South of the River Tweed ..................................................... 217

D. The Civil Law Tradition in Scotland ........................................... 219

E. Fennings v. Lord Grenville: The Elastic Application of Custom in English Law............................................................. 220

F. The Roman Law of Ferae Naturae Trumps Custom in Scottish

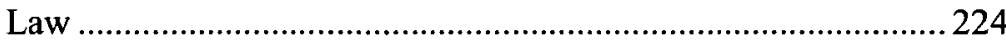

III. British Courts Shape Whaling Customs ............................................ 227

A. Hogarth v. Jackson: The Requirement that a Whale be Fast Gets a Bit Looser .................................................................... 227

B. Skinner v. Chapman: When a Loose Fish Remains Fast ..............231

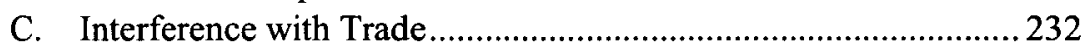

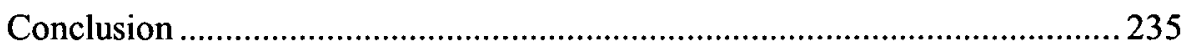

\section{INTRODUCTION}

"It frequently happens that when several ships are cruising in company, a whale may be struck by one vessel, then escape, and be finally killed and captured by another vessel," wrote Herman Melville in Moby-Dick. " "Thus the most vexatious and violent disputes would often arise between the fishermen, were there not some written or unwritten, universal, undisputed law applicable to all cases."2 Melville went on to state that American whalemen, acting as their own lawyers and legislators, created and enforced their own rules without statutory dictate or judicial guidance. Melville reduced the universal law that prevented such "vexatious and violent disputes" 3 to a pair of pithy maxims: "I. A Fast-Fish belongs to the party fast to it. II. A Loose-Fish is fair game for anybody who can soonest catch it." ${ }^{\text {"4 }}$

1. HeRman Melville, Moby-Dick OR, The Whale 432 (Harrison Hayford, Hershel Parker \& B. Thomas Tansell eds., Penguin Books 2003) (1851).

2. Id.

3. Id.

4. Id. at 433. Fast here means fastened. Id. 
Melville's summary raises more questions than it answers. What, for example, constituted a fast fish? How much control must a whaler have had over his prey before it was deemed fast? Melville's gloss provides some answers: "Alive or dead a fish is technically fast, when it is connected with an occupied ship or boat, by any medium at all controllable by the occupant or occupants, - a mast, an oar, a nine-inch cable, a telegraph wire, or a strand of cobweb, it is all the same." In Melville's telling, control of a whale's fate or even its movement was clearly not required. The fictive nature of control in obtaining the right to a whale was emphasized by Melville's further explanation that a whale was also "technically fast" when it carried the waif or other "recognised symbol of possession" of a ship that had the present ability and intention of taking the animal. ${ }^{6}$

The description of whaling norms in Moby-Dick captures much of the confusion and ambiguity that governed confrontations at sea. ${ }^{7}$ Melville seamlessly conflates two standards that would, if strictly applied, render different results. ${ }^{8}$ The "fast-fish, loose-fish" standard, which Melville deems the universal law, required that a physical connection between whale and boat or crew member be maintained to defeat the claims of a rival vessel. ${ }^{9}$ Yet he also introduces the norm of "iron holds the whale," which provided that a boat retained its claim to a whale, even in the absence of an attached line, if a properly marked harpoon remained fast and the ship continued in pursuit with the ability-absent interference- to capture its prey. ${ }^{10}$ Finally, Melville indicates that a third standard-justice-was also sometimes invoked by the more honorable whalemen to award whales to captains whose claims, while ethically compelling, were weak under the prevailing norms. ${ }^{11}$

How then did whalemen use such vague guidelines to settle arguments over a valuable commodity at a great distance from the formal institutions of the law? Melville answers the question concerning dispute resolution with a statement that belies his earlier observation that application of an undisputed law obviated violence: ${ }^{12}$

[T] he commentaries of the whalemen themselves sometimes consist in hard words and harder knocks-the Coke-upon-Littleton of the fist. True, among the more upright and honorable whalemen allowances are always

\footnotetext{
5. Id.

6. Id. A waif is a flag that is attached to a pole affixed to a dead whale.

7. See id. at $432-33$.

8. See id.

9. Id.

10. Id. For a discussion of the different norms used by whalemen, see ROBERT C. ELLICKSON, ORDER WITHOUt LAW: How NEIGHBORS SETTLE DiSPUTES 191-206 (1991) [herinafter ElLICKSON, ORDER WITHOUT LAW]; Robert C. Ellickson, A Hypothesis of Wealth-Maximizing Norms: Evidence from the Whaling Industry, 5 J.L. ECON. \& ORG. 83 (1989) [hereinafter Ellickson, A Hypothesis of Wealth-Maximizing Norms].
}

11. MELVILLE, supra note 1 , at 433

12. Id. 
made for peculiar cases, where it would be an outrageous moral injustice for one party to claim possession of a whale previously chased or killed by another party. But others are by no means so scrupulous. ${ }^{13}$

While historians, perhaps accepting Melville's dual explanation of peaceful agreement and violence, have paid little attention to how whalemen settled disputes over the capture of whales, legal scholars investigating the legal basis for ownership of nature have found such disputes illuminating. ${ }^{14}$ The legal status of whales and other wild animals, or what the law calls ferae naturae, was a standard feature in English law compilations ranging from Bracton's thirteenth century writings ${ }^{15}$ to Blackstone's eighteenth century treatises $^{16}$; indeed, much of the early nineteenth century American understanding of the common law of property was based on Blackstone. ${ }^{17}$ As the conversion of wild animals into personal property has waned as a subject of litigation, legal theorists such as Professor Robert C. Ellickson have found the whaling cases of the eighteenth and nineteenth centuries fruitful for understanding how property law is created and implemented. ${ }^{18}$ Is property law imposed upon society from above by judges and legislators, or do the formal institutions of the law merely endorse the norms and customs that are fashioned by those most intimately concerned with the relevant issues in the field-or, in the case of whaling law, on the open sea? ${ }^{19}$

If Melville's whalemen were willing to use or threaten violence, Ellickson portrays the same men as members of a close-knit community who were able to peacefully resolve potential disputes by creating norms that minimized the costs of doing business and maximized the welfare of all participants. ${ }^{20}$ Ellickson, a leading proponent of the idea that close-knit groups often resolve their own problems without recourse to legal institutions or even law, argues that nineteenth century whalemen operated on the basis of norms that were

13. Id. at 433-435. Coke-upon-Littleton is a reference to the first part of Edward Coke's 1628 Institutes of the Lawes of England. Generally referred to as Coke upon Littleton, it is a commentary on Thomas Littleton's fifteenth century treatise on property law. See Brian J. Moline, Early American Legal Education, 42 WASHBURN L. J. 775, 787 (2004); David N. Mayer, The English Radical Whig Origins of American Constitutionalism, 70 WASH. U. L. Q. 131, 176 (1992).

14. See, e.g., ElliCKSON, ORDER WITHOUT LAW, supra note 10, at 191-206; Ellickson, $A$ Hypothesis of Wealth-Maximizing Norms, supra note 10.

15. 1 HeNRY de BRACtON, De Legibus et Consuetudinibus ANGliaE 67 (1878)

16. See, e.g., 1 William BlaCKStone, COMMENTARIES ON the Laws of ENGland (12th ed. 1793).

17. Steve Sheppard, Casebooks, Commentaries, and Curmudgeons: An Introductory History of Law in the Lecture Hall, 82 IOWA L. REV. 547, 559-564 (1997).

18. See, e.g., ELLICKSON, ORDER WITHOUT LAW, supra note 10, at 191-206; Ellickson, $A$ Hypothesis of Wealth-Maximizing Norms, supra note 10.

19. See ELLICKSON, ORDER WITHOUT LAW, supra note 10, at 191-206; Ellickson, A Hypothesis of Wealth-Maximizing Norms, supra note 10.

20. ElliCKSON, ORDER WITHOUT LAW, supra note 10, at 191-206; Ellickson, A Hypothesis of Wealth-Maximizing Norms, supra note 10 , at 84 . 
enforced by a neighborly sense of shared pursuit. ${ }^{21}$ If a captain failed to play by the rules, he might be subjected to an escalating series of rebukes from his colleagues ranging from peer pressure to, on rare occasions, threats of violence. ${ }^{22}$ Central to Ellickson's theory is the existence of a series of norms that all participants understood. Without such common understanding, the informal mechanisms of enforcement that Ellickson postulates would not be effective. ${ }^{23}$

While Ellickson recognizes that customs changed over time and over the vast expanse of water, he maintains that whalemen in different historical fisheries created and enforced the evolving practices with little interference from courts and legislators. ${ }^{24}$ Ellickson's vision of how whaling law was created enjoys wide support. For instance, Professor Henry E. Smith has recently used whaling as an example of how property law can adopt "wholesale the customs developed by communities that stand in a special relationship to use conflicts." 25

But whaling law, contrary to Ellickson's view, was not created entirely at sea. The history of British whalemen resolving disputes in the Greenland fishery makes this clear, as does English and Scottish courts' adjudication of the handful of whaling cases actually litigated. British lawyers, judges, and legal scholars of the eighteenth and nineteenth centuries did not merely provide their imprimatur to that which was presented to them as whaling custom. The process by which the property law of whaling developed was, instead, collaboratively shaped by both whalers and legal professionals.

Part I of this Article examines the state of British whaling law at the beginning of the nineteenth century. An 1812 dispute between Captain William Scoresby, Jr., and his father, the master of a competing ship, reveals that while the custom of fast-fish, loose-fish was the prevailing norm of the Greenland fishery, notions of fairness and honor were also applied on occasion in settling disputes. Part II explains that prior to 1800 the custom of iron holds the whale was also followed by some whalemen hunting bowheads in the Greenland fishery. The demise of iron holds the whale as a custom followed in the fishery was primarily the result of a series of English court decisions, not evolution of custom. In the 1794 case of Addison v. Row, the House of Lords overturned the decision of a Scottish court that had proclaimed iron holds the whale to be the general rule of the fishery as it comported with principles of Roman law. The

21. ELLICKSON, ORDER WITHOUT LAW, supra note 10, at 191-206; Ellickson, A Hypothesis of Wealth-Maximizing Norms, supra note 10, at 85-87.

22. ElLICKSON, ORDER WITHOUT LAW, supra note 10, at 191-206, 213-219; Ellickson, $A$ Hypothesis of Wealth-Maximizing Norms, supra note 10, at 86.

23. ELLICKSON, ORDER WITHOUT LAW, supra note 10, at 191-206; Ellickson, A Hypothesis of Wealth-Maximizing Norms, supra note 10, at 85-87.

24. ElliCKSON, ORder WITHOUT LAW, supra note 10, at 191-206; Ellickson, A Hypothesis of Wealth-Maximizing Norms, supra note 10, at 84-85.

25. Henry E. Smith, Community and Custom in Property, 10 TheORETICAL INQ. L. 5, 6 (2009). 
decision of the House of Lords was based on its belief that the practice of fastfish, loose-fish constituted the custom of the fishery and must be followed. Part III shows how British courts by the 1820 s began to expand the definition of fastness to include whales that were not attached to a boat by a harpoon and line. This expansion did not reflect a change in practice by whalemen, but was produced by the application of the emerging action of interference with trade to cases where the results pursuant to fast-fish, loose-fish seemed unfair to the first striker. Aspects of the previously rejected custom of iron holds the whale were thereby reintroduced. The Article concludes with the observation that British whaling law was created by both whalemen and legal professionals. British courts did not, as Ellickson suggests, simply adopt whaling customs.

\section{THE GREENLAND WHALEFISHERY OF THE CAPTAINS SCORESBY}

Captain William Scoresby, Jr., an early nineteenth century whaleman and scientist, wrote extensively about contemporary whaling customs and practices. ${ }^{26}$ While he praised the certainty and efficiency of the prevailing norm of fast-fish, loose-fish, Scoresby also indicated that honorable whalemen occasionally deviated from these customs to avoid an unjust result. ${ }^{27}$ Scoresby's 1812 dispute with his father-the captain of a competing whalerreveals the fluidity of whaling customs and the often improvisational nature of dispute resolution at sea. ${ }^{28}$

\section{A. The Challenges of Whaling in Arctic Waters}

January 1812 brought a familiar ritual to the port of Whitby on England's northeast coast. Captains began stocking their vessels for the summer season in the Greenland whalefishery. ${ }^{29}$ Since 1753, Whitby had sent its ships into Arctic waters in pursuit of bowheads or what locals called the Greenland or Common whale. ${ }^{30}$ Captain William Scoresby, Jr., had every reason to be optimistic about

26. For a brief biographical sketch of William Scoresby, see THE ARCTIC WHALING JOURNALS OF WILlIAM SCORESBY THE YOUNGER: VOLUME I, THE VOYAGES OF 1811, 1812 AND 1813, xxi-xxxiii (C. Ian Jackson, ed., 2003) [herinafter THE ARCTIC WHALING JOURNALS OF William SCORESBY]. Scoresby's careers as whaling captain, scientist, and cleric are also addressed in Michael Bravo, Geographies of Exploration and Improvement: William Scoresby and Arctic Whaling, 1782-1882, $32 \mathrm{~J}$. OF HIST. GEOGRAPHY 512 (2006); Anita McConnell, The Scientific Life of William Scoresby, Jnr, with a Catalogue of his Instruments and Apparatus in the Whitby Museum, 43 ANNALS OF SCI. 257 (1986); Constance Martin, William Scoresby, Jr. (1789-1857) and the Open Polar Sea-Myth and Reality, 41 ARCTIC 39 (1988). The most recent full biography of Scoresby is TOM STAMP \& CORDELIA STAMP, WILLIAM SCORESBY, ARCTIC EXPLORER (1975).

27. See 2 William SCORESBY, AN ACCOUNT OF THE ARCTIC REgIONS WITH A HiSTORY AND DESCRIPTION OF THE NORTHERN WHALE-FISHERY 312-333 (reprint 1969) (1820) [hereinafter 2 SCORESBY, AN ACCOUNT OF THE ARCTIC REGIONS].

28. See THE ARCTIC WHALING JOURNALS OF WILLIAM SCORESBY, supra note 26, at 119-120.

29. Id. at 63 .

30. The scientific name for the bowhead whale is Balaena mysticetus. J. Jerome Montague, Introduction, in THE BOWHEAD WHALE I (John J. Burns et al., eds., 1993). Although the word bowhead was not used by the British, it is employed throughout as it has come to be the most common name for 
the upcoming season as the meat of twenty-six and a half pigs was salted, packed, and stowed aboard the Resolution in early January. ${ }^{31}$ The Yorkshireborn child of a whaling master of the same name, Scoresby was introduced to Arctic waters at age ten on his father's 1800 summer voyage to the Greenland fishery. ${ }^{32}$ By 1803 , the younger Scoresby served as an apprentice in his father's employ, and at age sixteen he was promoted to first mate. ${ }^{33}$ Scoresby had enjoyed much success in 1811 , rewarding the faith that the owners of the Resolution placed in the twenty-one-year-old novice captain. ${ }^{34}$

The timing of the Resolution's March 27 departure from Whitby for the 1812 Greenland whaling season was dictated by a confluence of factors relating to meteorology, oceanography, glaciology, early nineteenth century maritime technology, and the patterns of bowhead migration. As Scoresby explained, the conditions prior to the middle of April in the bowhead laden areas north of $75^{\circ}$ latitude were simply too dangerous. ${ }^{35}$ The risk of encountering prevalent drift ice in the dark prior to the spring advent of twenty-four-hour daylight far outweighed any advantage an early start to the whaling season might provide. ${ }^{36}$ The combination of ice, darkness, severe frost, and storms before the middle of April "probably produce[d] as high a degree of horror in the mind of the navigator ... as any combination of circumstances which the imagination can present." 37 However, Scoresby's fellow captains were also concerned that their competitors might beat them to the whales. A captain with a head start over his colleagues might, in a single week with a herd of bowheads, guarantee a profitable season before other masters had even spied a single whale. ${ }^{38}$

Captains' gamesmanship in timing their departures from Whitby was a mere prelude to the constant interaction between masters that marked any season in a whalefishery. Whaling was, fundamentally, a group endeavor. Whalemen were intensely competitive yet at the same time remarkably collegial-and, on occasion, extremely generous. ${ }^{39}$ Captains were well aware that their success depended on watching the movements of other ships through the ice and sharing information about conditions and bowhead locations with

Balaena mysticetus. Id. at 1 . First used by American whalemen in the nineteenth century, the name bowhead is a reference to the animal's bow-shaped skull. Id. at 1; JOHN BOCKSTOCE, WHALES, ICE, AND MEN: THE HISTORY OF WHALING IN THE WESTERN ARCTIC 21-26 (1986).

31. ARCTIC WHALING JOURNALS OF WILLIAM SCORESBY, supra note 26 , at 63.

32. Id. at xxvii.

33. Id.

34. For the results of the Resolution during the 1811 season, see id. at 58.

35. 2 SCORESBY, AN ACCOUNT OF THE ARCTIC REGIONS, supra note 27, at 208.

36. Id.

37. Id. at 207.

38. Id. at 206-209.

39. For an example of competing crews coming to the rescue of a ship in danger, see id. at 446 49. 
their fellow masters. ${ }^{40}$ Scoresby, like all whaling captains, recognized that the master whose miscalculation of ice conditions could be exploited to gain a whale, might later prove savior should the Resolution find itself trapped in the ice. As competitors and allies in a shared battle in a harsh environment, where the flick of a bowhead's tail or the tardy cutting of a line attached to a sounding whale could mean death, how did British whalers resolve ownership disputes over their valuable quarry? ${ }^{41}$

\section{B. An "Equitable System of Regulation"}

Scoresby was very clear, in his 1820 An Account of the Arctic Regions with a Description of the Northern Whale-Fishery, that whalemen had, in the absence of legislation, created their own "equitable system of regulations" that curbed the greed of individual captains and worked to the "mutual benefit" of all. $^{42} \mathrm{He}$ explained that the Greenland practice of fast-fish, loose-fish discouraged litigation and prevented whales from escaping capture. ${ }^{43}$ Scoresby indicated that when a whale was struck by a harpoon it became the property of the ship that dealt the blow. ${ }^{44}$ Possession was retained so long as the whaler maintained that connection through the harpoon and lines to the animal. ${ }^{45}$

Even if the line rested so tenuously upon the whale that escape could be easily achieved, possession was still possible. ${ }^{46}$ If, at the moment after a second whaler inflicted a fatal wound, the line of the original hunter should lose its connection to the whale, the first striker would still be entitled to possession. ${ }^{47}$ The claim of a first striker was bolstered by the mechanism for determining whether a whale was fast when a second whaler joined the fray: ${ }^{48}$ upon harpooning a whale, a whaleboat and its mother ship each hoisted a flag, specifically a jack, to signal friends for assistance and to warn off competitors. ${ }^{49} \mathrm{~A}$ whaler flying the jack was presumed to remain fast to a whale unless the second ship could present convincing evidence to the contrary. ${ }^{50}$ The competitor's claim was always subject to the compelling rejoinder that a

40. Scoresby's journal of his 1812 voyage to the Greenland fishery contains a good example of the attention captains paid to the positions of other ships in icy waters. See, e.g., ARCTIC WHALING JOURNALS OF WILLIAM SCORESBY, supra note 26, at 88-97.

41. For the dangers of whaling in the Greenland fishery, see 2 SCORESBY, AN ACCOUNT OF THE ARCTIC REGIONS, supra note 27 , at $340-68$.

42. Id. at 312 .

43. Id. at 324-25.

44. Id. at 319 .

45. Id.

46. Id. at 321 .

47. Id. at 320 .

48. Id. at 250 .

49. Id. British whaling vessels were referred to as ships and carried a number of small boats from which a half dozen or so members of the crew would attack a whale at close range. The boats were generally suspended from davits on a ship's side and lowered when a whale was spied. 2 SCORESBY, AN ACCOUNT OF THE ARCTIC REGIONS, supra note 27, at 221-23, 230-37.

50. Id. at 320 . 
displaced line may well have maintained contact with the whale beneath the water's surface and out of view. ${ }^{51}$

If the fast-fish provisions favored the original striker, the loose-fish component worked to the advantage of an intervening whaler. Once a whale was loose, regardless of the circumstances, it was free for the taking. ${ }^{52}$ The harshness of this rule was illustrated by Scoresby's hypothetical example of a ship with a dead whale in tow awaiting a storm's passage before cutting in. ${ }^{53}$ If the line broke, a second whaler would be free to claim the animal. ${ }^{54}$ Scoresby acknowledged that this custom might appear unfair. ${ }^{55}$

He defended the Greenland practice, however, with the observation that it prevented whales from escaping capture and diminished the likelihood of litigation. ${ }^{56}$ After all, if a ship could maintain legal possession of a whale after losing physical connection to it, an issue would arise regarding what constituted sufficient proximity for the original striker to retain possession. ${ }^{57} \mathrm{~A}$ second whaler would, under this framework, hesitate to pursue a loose whale out of fear that his effort would go unrewarded or result in expensive litigation should he capture the animal. ${ }^{58}$ The end result, Scoresby explained from his perspective as a captain, would be unfortunate: the Greenland fishery would fail to yield its maximum economic return. ${ }^{59}$ Yet the universal respect for these principles established by custom in the Greenland fishery seemed to evaporate in their actual application at sea. ${ }^{60}$ What at first glance appeared simple and certain became a good deal messier in practice. ${ }^{61}$

After extolling the practical virtues of fast-fish, loose-fish, Scoresby suggested that the rules of whaling would be improved by observance of the golden rule from Matthew 7:12: "do unto others as you would have them do unto you." 62 Scoresby asserted that to take a whale bearing the harpoon, but not the line, of another ship constituted robbery and "that nothing could justify such an act, but the certainty, that the original strikers could have little or no chance of ever recovering the possession of the fish themselves."63 Particular note was taken of a captain who sent his boats to assist in the taking of a whale fast to a competitor's ship. ${ }^{64}$ Should that whale become loose, Scoresby said, "according to principles of right and strict honour, I conceive it is the property

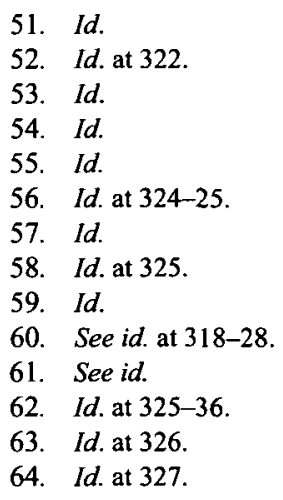


of the first striker, and as such, ought to be given up." 65 Having provided several examples of the unfairness of fast-fish, loose-fish, Scoresby-despite his obvious preference for a rule that allowed a harpoon to mark a whale for future capture-lamented that the economic self-interest of whalemen clouded the "integrity of character" needed to permit adoption of a new rule. ${ }^{66}$

\section{C. "By the Laws of Honour"}

Scoresby's logbook for the Resolution's 1812 voyage may provide an explanation for his conflicted feelings on this topic. On July 21,1812 , at about $78^{\circ}$ north and $4^{\circ}$ east in the prime bowhead grounds near Spitzbergen, the crew of the Resolution was determined to spend their final few days in the fishery profitably before returning home. ${ }^{67}$ The Resolution, having followed the John through some ice, encountered several bowheads. ${ }^{68}$ One of the boats belonging to the Resolution attempted to strike a whale, but its harpoons failed to stay fast. ${ }^{69}$ Disappointed, Scoresby ordered his boats to assist the John in capturing a fast whale that was running their competitor's line toward the Resolution. ${ }^{70}$

Scoresby's decision to assist the John would not have been viewed by his crew as an unusual order. ${ }^{71}$ Captains often directed that such assistance be rendered. ${ }^{72}$ While such aid was not rewarded with a share of the captured whale, the help was recognized as part of a code of behavior that urged recipients of assistance to reciprocate the favor to another vessel. ${ }^{73}$ Had the John's line remained fast, any harpoons from the Resolution that found their mark would have been deemed "friendly" and returned to the latter with a show of appreciation when the target of the chase was captured. ${ }^{74}$

As frequently happened, however, the John's harpoon drew loose. ${ }^{75}$ The whale that the Resolution had pursued for the previous hour on behalf of the John was now, according to a strict interpretation of fast-fish, loose-fish, free for the taking. The Resolution managed thereafter to affix a harpoon and take the whale. ${ }^{76}$

65. Id.

66. Id. at 326 .

67. ARCTIC WHALING JOURNALS OF WILLIAM SCORESBY, supra note 26 , at 119-120. For Scoresby's journal of the entire 1812 season, see $i d$. at 63-127.

68. Id. at 119 .

69. Id.

70. Id.

71. Scoresby's discussion of the laws of whaling makes clear that the rendering of such aid was a common occurrence. Id. at $250,320,327$, and $346-48$.

72. Id.

73. $1 d$.

74. For the concept of a friendly harpoon, see Littledale v. Scaith, 1 Taunt. 241, 243, 127 Eng. Rep. 825, 826 (1788).

75. ARCTIC WhaLING JOURNALS OF WILLIAM SCORESBY, supra note 26, at 119

76. Id. 
As a twenty-two year old captain in only his second year in command, Scoresby faced a serious challenge. His crew was adamant that, pursuant to the custom of the fishery, the whale was rightfully the sole property of the Resolution. ${ }^{77}$ Scoresby concurred that they had a legal right to the whale, but argued that "by the laws of honour" the claim of the John should prevail. ${ }^{78}$ The Resolution, after all, had rendered aid with the intent that the John should take the prize. Scoresby's men would never have been able to take the whale without the actions of the John in originally striking and wounding the creature. The crew of the Resolution countered that the John had fallen off the pace of the whale once it swam free of its harpoon and would never have successfully closed the gap. ${ }^{79}$ The crew also, in arguing for a strict application of fast-fish, loose-fish, introduced the essential element of "iron holds the whale": the likelihood that the John would have captured its quarry without the assistance of the Resolution.

Scoresby's dilemma was complicated by the fact that his father was the captain of the John ${ }^{80}$ Revered as one of England's most innovative whalemen, Captain William Scoresby, Sr., was an imposing figure. ${ }^{81}$ In addition to the normal familial bonds, the younger Scoresby almost certainly owed his command to his father's influence. 82 As the crew of the Resolution was doubtless well aware, the father had passed the ship's command to his son when he assumed the captaincy of the John the previous year. ${ }^{83}$ The son's discomfort is evident in the pages of the Resolution's logbook. "In this dilema [sic] placed between the duty as a Master and duty as a Son which had opposite actions I was in an unhappy strait." ${ }^{\prime 84}$ A similar conflict with any other vessel would have permitted Scoresby to do what he considered honorable and surrender the whale free of the accusation that he was acting in the thrall of his father's influence. ${ }^{85}$

However, in a move that might have struck his crew as desperate and undermined his authority, Scoresby argued that his father was "wroth." 86 That the captain of the John was extremely angry meant little to the crew of the

77. $1 d$

78. $I d$.

79. Id.

80. Id. at $119-20$.

81. For Scoresby's own assessment of his father's ability to intimidate others through his physical strength and forceful personality, see WILLIAM SCORESBY, MEMORIALS OF THE SEA. MY FATHER: BEING RECORDS OF THE ADVENTUROUS LIFE OF THE LATE WILLIAM SCORESBY, ESQ. OF WHITBY 2123 (1851). The younger Scoresby did not make reference to his unpleasant 1812 encounter with his father when he penned his biography of the latter nearly forty years later. In addition to the biography of his son, for an account of the elder Scoresby's career as a whaling captain, see ARCTIC WHALING JOURNALS OF WILLIAM SCORESBY, supra note 26 , at xxvi-xxviii.

82. ARCTIC WHALING JOURNALS OF WILLIAM SCORESBY, supra note 26, at 1-li.

83. Id.

84. Id. at 119.

85. Id. at $119-20$.

86. Id. at 119. 
Resolution, convinced that the whale was rightfully theirs. ${ }^{87}$ In an attempt to resolve the dispute to the satisfaction of all, Scoresby boarded the John to speak with his father. ${ }^{88}$

Scoresby's initial suggestion was that they simply split the whale..$^{89}$ The elder Scoresby was not immediately disposed to follow this course. ${ }^{90}$ After much discussion, however, the John's master agreed, or so it appeared. ${ }^{91}$ While the logbook account is a bit cryptic, the elder Scoresby apparently reverted suddenly to his earlier state of rage.$^{92} \mathrm{He}$ blamed his son for the entire situation and threatened to enforce his legal right to the disputed whale once he returned to England.$^{93}$ Disconsolate, Scoresby returned to the Resolution where the crew began removing the whale's blubber for storage. ${ }^{94}$ Likely seeking some sort of reconciliation with his father, Scoresby thereafter had his ship draw up close to the John ${ }^{95}$ The logbook entry for the day ends with a statement that both described the ship's position and captured the mood of its author: "The Ice seems to have quite enclosed us." 96

This incident, like most disputes over captured whales, did not end in litigation. Was the elder Scoresby's threat of legal action merely empty invective shouted in frustration at a lost whale, or was it made in the hope that the courts might provide some relief? A quick review of the reported British cases suggests that Scoresby's father probably knew full well that any court would award the whale as a loose fish to the Resolution. ${ }^{97}$ As early as 1786 , courts resolved a dispute between two British whalers by the application of fast-fish, loose-fish. The Times of London reported that Justice Buller of the Court of King's Bench instructed the jury that according to the law of the Greenland whalefishery any fast whale that "gets loose by any means, though she has a harpoon and lines about her," may be taken by another ship. ${ }^{98}$

\footnotetext{
87. Id.

88. Id. at $119-20$.

89. Id. at 120.

90. Id.

91. Id.

92. Id.

93. Id.

94. Id.

95. Id.

96. Id.

97. While it is impossible to know if the elder Scoresby was aware of cases resolving whaling property disputes, it is certainly likely as cases were reported in British newspapers and his son discussed the matter of Gale $v$. Wilkinson and even attached an account of that trial in the second volume of his An Account of the Arctic Regions. See 2 SCORESBY, AN ACCOUNT OF THE ARCTIC REGIONS, supra note 27, at 323, 518-21. A 1791 trial involving the Simon and the Nautilus was, for example, reported in at least two British newspapers. See The Owners of the Ship Simon, v. the Owners of the Ship Nautilus, EvenING MAIL (London), Dec. 19, 1791; The Owners of the Ship Simon, v. the Owners of the Ship Nautilus, Times (London), Dec. 21, 1791, at 3.

98. The 1786 matter before Justice Buller was not preserved in any of the volumes of reported cases from which lawyers and judges in common law jurisdictions find precedents. However, the matter was related in a British newspaper. See Law Intelligence, TIMES (London), Dec. 29, 1786, at 3. For a
} 
Littledale v. Scaith, decided at the York Lent Assizes in 1788, provided a clear statement of fast-fish, loose-fish that most judges and legal commentators cited throughout the nineteenth century as the universally accepted custom of the Greenland fishery. ${ }^{99}$

Yet the elder Scoresby's threat of litigation was not made without some basis in the law and the practices of the Greenland fishery. Despite frequent speculation in the nineteenth century that the custom as set forth in Littledale had been followed since the dawn of Greenland whaling, and despite the tendency of many courts and commentators to view fast-fish, loose-fish as rigid and unchanging, the custom was, in fact, a fairly recent development and-as Scoresby's experience suggests - was never uniformly applied at sea. ${ }^{100}$

\section{ENGLISH COURTS ESTABLISH "FAST-FISH, LOOSE-FISH"} AS THE LAW OF WHALING

Prior to 1800 , the customs of iron holds the whale and fast-fish, loose-fish were both followed by whalemen in the Greenland fishery. Scottish judgesadhering to the general principles of Roman law-preferred the practice of iron holds the whale. However, on appeal, English jurists deemed fast-fish, loosefish to be the binding custom of the fishery. ${ }^{101}$

\section{A. Dutch Whaling Customs and Statutes}

Spitzbergen-or Svalbard, as it is known at present - is an archipelago approximately halfway between Norway and the North Pole. Although the Vikings may have known of its existence, the Dutch explorer William Barents discovered an island he dubbed Spitzbergen in 1596. ${ }^{102}$ In 1607 , the English

brief account of Justice Francis Buller's career, see 1 WILLIAM C. TOWNSEND, THE LIVES OF TWELVE EMINENT JUDGES OF THE LAST AND OF THE PRESENT CENTURY 1-32 (1846).

99. See Littledale v. Scaith, 1 Taunt. 241,243 (1788). Littledale is appended as a note in the reported Galapagos Island whaling dispute Fennings v. Lord Grenville, 1 Taunt. 241, 243, 127 Eng. Rep. 825, 826 (1808).

100. For speculation as to the antiquity of Greenland custom, see, for example, the argument of counsel in Fennings. 1 Taunt. at 243-44.

101. Scottish cases were subject to appeal before the House of Lords since the Union of 1707. For a discussion of the House of Lords hearing appeals from the Court of Session after 1707, see David M. Walker, Some Characteristics of Scots Law, 18 MOD. L. REV. 321 (1955).

102. For discussion of Barents and Hudson and their discovery of Spitzbergen, see LANCE E. Davis et al., In Pursuit of Leviathan: Technology, Institutions, Productivity, and Profits IN AMERICAN WHALING, 1816-1906, at 31-34 (1997); Robert C. Allen \& Ian Keay, Bowhead Whales in the Eastern Arctic, 1611-1911: Population Reconstruction with Historical Whaling Records, 12 ENV'T \& HIST. 89 (2006) [hereinafter Allen \& Keay, Bowhead Whales in the Eastern Arctic]; Robert C. Allen \& Ian Keay, Saving the Whales: Lessons from the Extinction of the Eastern Arctic Bowhead, 64 J. ECON. HIST. 400 (2004) [hereinafter Allen \& Keay, Saving the Whales]; Louwrens Hacquebord et al., English and Dutch Whaling Stations in Spitsbergen (Svalbard) before 1660, 15 INT'L J. OF MAR. HIST. 117 (2003); Robert C. Allen \& Ian Keay, The First Great Whale Extinction: The End of the Bowhead Whale in the Eastern Arctic, 38 EXPLORATIONS IN ECON. HIST. 448 (2001) [hereinafter Allen \& Keay, The First Great Whale Extinction]; John J. Teal, Europe's Northernmost Frontier, 29 FoREIGN AFF. 263 (Jan. 1951). 
explorer Henry Hudson, sailing under a Dutch flag, further investigated the island's coastline. ${ }^{103}$ Barents and Hudson had reached the largest and nearly westernmost island of the archipelago. About 280 miles long and anywhere from 25 to 140 miles in width, the island, also sometimes called West Spitzbergen, is situated along an extension of the Gulf Stream, which keeps the icy waters off its western coast open to navigation approximately six months each year. ${ }^{104}$

Although Hudson's investigation of Spitzbergen did nothing to advance his goal of finding the hoped-for Northeast Passage to the Pacific, he recognized the commercial possibilities of the region. ${ }^{105}$ Spitzbergen's many harbors abounded with bone-laden and oil-rich bowhead whales. ${ }^{106}$ At the time of the discovery, European commercial whaling had been mostly shore-based and generally limited to Basque hunters; their fishing was primarily consigned to areas off the beaches of southwest France and, secondarily, North America's northeast coast. ${ }^{107}$ The abundant bowheads in the bays off the west coast of Spitzbergen were ideal for the prevailing whaling technique whereby spotters on beach towers would alert crews of generally six men to put to sea at a moment's notice in pursuit of prey. ${ }^{108}$ Similar crews in nearby small boats were then summoned to assist in the harpooning and lancing of the targeted whale. ${ }^{109}$

The Dutch, British, Germans, and Basque quickly established shore-based operations, setting off contentious battles-occasionally with the use of armsfor the best harbors. ${ }^{110}$ Shore-based whaling, with its use of buildings to boil blubber, store oil, and house workers, precluded the creative, spontaneous decision making that so marked a successful pelagic captain. Anchored to a particular location for an entire season, shore-based whalemen displayed a

103. DAVIS ET AL., supra note 102, at 31 .

104. For the basic geography of the archipelago, see 18 MASOOD ALI KHAN, AFZAL SHERIEEF \& A. BALAKISHAN, ENCYCLOPEDIA OF WORLD GEOGRAPHY 183 (2007). Spitzbergen has retained a dual meaning. It can refer to both the largest island and the entire archipelago. As English whalemen in seventeenth and eighteenth century generally spelled the island "Spitzbergen," rather than the more modern "Spitsbergen," the older spelling has been employed throughout. Central Intelligence Agency, The World Factbook, Svalbad, https://www.cia.gov/library/publications/the-world-factbook/geos/ sv.html (last visited Jan. 26, 2010). For the warm West Spitsbergen Current, see Univ. of Miami, Rosensteil School of Marine and Atmospheric Science, The Spitsbergen Current, http://oceancurrents. rsmas.miami.edu/atlantic/spitsbergen.html (last visited Jan. 26, 2010).

105. DAVIS ET AL., supra note 102, at 31 .

106. Allen \& Keay, The First Great Whale Extinction, supra note 102, at 449.

107. For discussion of Basque whaling, see ERIC JAY DOLIN, LEVIATHAN: THE HISTORY OF Whaling IN AMERICA 21-24 (2007); Aldemaro Romero \& Shelly Kannada, Comment on "Genetic Analysis of 16th-Century Whale Bones Prompts Revision of the Impact of Basque Whaling on Right and Bowhead Whales in the Western North Atlantic, 84 CAN. J. OF ZoologY 1059 (2006); Selma Huxley Barkham, The Basque Whaling Establishments in Labrador 1536-1632 - A Summary, 37 ARCTIC 515 (1984).

108. DOLIN, supra note 107 , at 49.

109. Id.

110. 2 SCORESBY, AN ACCOUNT OF THE ARCTIC REGIONS, supra note 27, at 100-01. 
territoriality that disappeared once ships ventured out to sea for extended periods of time. As whaling historian Gordon Jackson has remarked, the English effort in the first years of Spitzbergen whaling was directed more at excluding the Dutch than at actually killing whales. ${ }^{11}$

Violence and the threat of further disruptions to oil harvesting led the participating nations to establish an agreement assigning Spitzbergen harbors by nationality prior to the 1619 season. ${ }^{112}$ While the 1619 assignment of harbors was initially viewed as a victory for the British, the Dutch were relegated to the particularly advantageous northern coast of Spitzbergen. ${ }^{113}$ This allowed the Dutch to gain their first experience of pelagic whaling in an area that would prove to be the Greenland fishery's most productive hunting grounds. By 1650, the Dutch began a century as the preeminent European whaling nation. ${ }^{114}$

The Dutch, unlike the British and later the Americans, provided statutory guidance concerning disputed whales. The States-General of Holland and West Friesland enacted in 1695 a comprehensive set of laws governing the whaling industry. ${ }^{115}$ Each captain and chief officer was required to take an oath prior to departure swearing adherence to the regulations. ${ }^{116}$ Revising an unsuccessful code promulgated in 1677, the new law provided among its twelve articles:

9. Any one having killed a whale in the ice, but who cannot conveniently take it on board, shall be considered as the owner thereof, so long as any of

111. Gordon Jackson, Government Bounties and the Establishment of the Scottish Whaling Trade, 1750-1800, in SCOTTISH THEMES: EsSAYS IN HONOUR OF PROFESSOR S. G. E. LYTHE 46, 47 (John Butt \& J. T. Ward, eds., 1976).

112. DAVIS ET AL., supra note 102, at 32.

113. Id.

114. See DAVIS ET AL., supra note 102, at 31-34; GORDON JACKSON, THE BRITISH WHALING TRADE 11-26 (1978); Allen \& Keay, Bowhead Whales in the Eastern Arctic, supra note 102, at 90-95; Allen \& Keay, Saving the Whales, supra note 102, at 400-01; Hacquebord, supra note 102, at 129-33; Allen \& Keay, The First Great Whale Extinction, supra note 102, at 448-51. The Dutch ultimately took control of the Greenland fishery for a number of reasons. For the advantages the Dutch enjoyed in labor productivity in whaling, see Christiaan van Bochove \& Jan Luiten van Zanden, Two Engines of Early Modern Growth? Herring Fisheries and Whaling during the Dutch Golden Age (1600-1800), in RICCHEZZA DEL MARE SECC XIII-XVIII 557-74 (Simonetta Cavaciocchi ed., 2006). While dealing with issues of productivity for other areas of Dutch maritime activity, the following unpublished draft article is suggestive for the whaling industry. Milja van Tielhof \& Jan Luiten van Zanden, Productivity Changes in Shipping in the Dutch Republic: the Evidence from Freight Rates, 1550-1800, http://www.iisg.nl/research/productivity-shipping-app.pdf (last visited Jan. 12, 2010). For the ability of Dutch merchants to shape government policy in ways favorable to their interests, see J. Braat, Dutch Activities in the North and the Arctic during the Sixteenth and Seventeenth Centuries, 37 ARCTIC 473 (1984); Jelle C. Riemersma, Oceanic Expansion: Government Influence on Company Organization in Holland and England (1550-1650), 10 J. OF ECON, HiST. 31 (1950). The Dutch asserted that the waters near Spitzbergen constituted mare liberum and thus the bowheads in the archipelago's bays were not the property of any one nation. The English argued-somewhat tortuously-that they had established sovereignty over Spitzbergen and its bowheads. See Torbjørn Pedersen, The Svalbard Continental Shelf Controversy: Legal Disputes and Political Rivalries, 37 OCEAN DEV. \& INT'L L. 339, 340 (2006). For the legal disputes over Svalbard which, since 1920, has been under Norwegian control, see $i d$.

115. 2 SCORESBY, AN ACCOUNT OF THE ARCTIC REGIONS, supra note 26, at 312-18.

116. Id. at 318 . 
his crew remains along with it; but whenever it is deserted, though made fast to a piece of ice, it becomes the property of the first who can get possession of it.

10. But if a fish be made fast to the shore, or moored near the shore by means of a grapnel or anchor, with a buoy, a flag, or other mark attached to it, signifying that it is not deserted,- - the person who left it there, shall still be considered the sole proprietor, though no person may be with it. ${ }^{117}$

The Dutch law reflects the mid to late seventeenth century transition from shore-based whaling to pelagic whaling. Both of the above-listed provisions governed situations where a whale had been killed but for some reason could not be immediately taken back to the ship or shore to be rendered. ${ }^{18}$ The burden was on the successful whaler to demonstrate to other hunters his control over the carcass. ${ }^{119}$ Unless the whale was anchored close to shore and marked with a flag or some other sign of possession, a crew member needed to remain with the body. ${ }^{120}$ Marking a whale that was fast to the ice with a buoy or flag was not sufficient. ${ }^{121}$

Perhaps the requirement that a whale attached to ice have a human companion was an acknowledgement that drifting ice might prevent the boat that inflicted the mortal blow from finding and reclaiming the animal. The logic was likely that it was better for the efforts of one whaler to go unrewarded than for a valuable commodity to go unclaimed by a second whaler who, seeing a flagged and deserted whale at sea, allowed it to drift off. The presence of a crew member was, in effect, insurance that a boat would return for both man and whale. The anchoring of a dead whale near the beach - a common practice in shore-based whaling-required no such assurance of the captor's return. ${ }^{122}$ In the shallow water near to whaling stations there was no danger that an anchored whale would go unused, since whalemen retained a strong sense of territorial possession over particular bays and harbors. ${ }^{123}$

\section{B. The Custom of "Iron Holds the Whale" in the Early Greenland Fishery}

The Dutch provisions did not address the familiar situation at sea where two or more ships actively pursued a live whale. The resolution of such disputes in the late seventeenth century appears to have been framed in the terms of the ancient debate between Roman lawyers over ownership of wild

117. Id. at 316-17.

118. See id.

119. Id.

120. Id.

121. Id.

122. Id. at 317 .

123. Id. at 38 . 
animals. ${ }^{124}$ Roman authorities such as Trebatius and Gaius agreed that the mere pursuit of a wild animal did not confer ownership. ${ }^{125}$ The pursuer must possess the creature, ${ }^{126}$ but scholars differed as to what constituted possession. Gaius argued that nothing less than the actual physical possession of the beast sufficed to gain title. ${ }^{127}$ Trebatius, on the other hand, asserted that possession vested prior to capture if the first pursuer inflicted a severe wound and maintained a pursuit that left the animal little chance of escape. ${ }^{128}$ In such a situation the creature was deprived of its freedom and brought within the power of the hunter. ${ }^{129}$

According to James Dalrymple, the first Viscount of Stair, the notion of possession advanced by Trebatius prevailed in the Greenland whalefishery of the late seventeenth century. ${ }^{130}$ In his 1681 discussion of ferae naturae, Dalrymple explained that the Greenland whaleman who "woundeth a whale so that she cannot keep the sea for the smart of her wound, and so must needs come to land, is proprietar, and not he that lays first hand on her at land."131 Dalrymple's discussion of possession in the Greenland fishery, however, was not limited to whales that drifted ashore. He indicated that a similar custom was applied to whales that were pursued at sea. ${ }^{132} \mathrm{~A}$ whaleman in sole pursuit of a whale with "a probability to reach his prey" was awarded the prize even if another vessel ultimately captured the animal. ${ }^{133}$

Dalrymple illustrated Greenland whaling custom by referencing a 1677 case decided by the Court of Session in Scotland, The King's Frigate against a Scots Caper. ${ }^{134}$ During the Anglo-Dutch Wars, an English frigate and an allied French vessel captured a Dutch privateer in possession of three captured vessels, or "prizes." 135 When two additional Dutch ships attempted to rescue their countrymen, one of the prize vessels, the Tortoise, attempted to make its escape. ${ }^{136}$ After chasing the Dutch interlopers away, the English and French

124. JAMES DALRYMPLE, Viscount of STAIR, THE InSTITUTIONS OF THE LAW OF SCOTLAND,

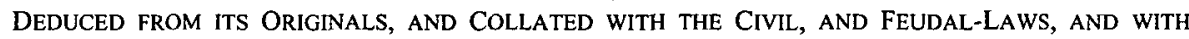
Customs of NeIGHBoring NATIONS, BoOK II, TITLE I, SECTION XXXIII 179-80 (1759).

125. Michael C. Blumm \& Lucas Ritchie, The Pioneer Spirit and the Public Trust: The American Rule of Capture and State Ownership of Wildlife, 35 ENVTL. L. 673, 677-78 n. 24 (2005).

126. Id. at $677-78$.

127. $I d$.

128. Steven M. Wise, The Legal Thinghood of Nonhuman Animals, 23 B. C. ENVTL. AFF. L. REV. 471, 496-97 (1996).

129. Id.

130. DALRYMPLE, supra note 124 , at $179-80$. Legal historians frequently refer to Dalrymple as Stair. See, e.g., Peter Birks \& Grant McLeod, The Implied Contract Theory of Quasi-Contract: Civilian Opinion Current in the Century before Blackstone, 6 OXFORD J. OF LEGAL STUD. 56 (1986).

131. Id. at 179 .

132. Id. at $179-80$.

133. Id.

134. Id. at 180. See also The King's Frigate against a Scots Caper, 3 Bro. Supp. to Mor. 125 (1677).

135. The King 's Frigate against a Scots Caper, 3 Bro. Supp. to Mor. at 125.

136. Id. 
frigates turned their attention to recovering the Tortoise. ${ }^{137}$ A Scottish privateer intervened, however, and captured the Tortoise. ${ }^{138}$ The resulting 1677 litigation over the prize was decided by the Court of Session in favor of the Scottish privateer. ${ }^{139}$ Dalrymple explained that the Scottish high court-applying Trebatius' rationale concerning possession of a wild animal-determined that despite its damaged condition the Tortoise would have made good its escape if not for the actions of the Scottish privateer. ${ }^{140} \mathrm{Had}$ the evidence shown that the English frigate was in position, absent interference, to capture the prize, the result would have been different. ${ }^{141}$

The custom of the Greenland whalefishery, as explained by Dalrymple, was not entirely clear. How certain, for example, must the capture of a whale by the first striker be before ownership would be awarded? Dalrymple indicated at one point in his discussion that a mere probability was sufficient, yet he also related that the Scottish privateer prevailed because the English frigate captain failed to meet an apparently higher standard: he failed to prove that absent interference the frigate would have captured the Tortoise. ${ }^{142}$ Aside from the lack of a clear standard of proof, Dalrymple also suggested that a pursuing first striker need not seriously injury a whale in order to gain possession prior to the actual capture of the animal. ${ }^{143}$ The pursuit of a whale, coupled with the probability of success, appeared - in some circumstancessufficient to secure ownership. ${ }^{144}$

A 1778-79 geography text and a 1792 ruling by the Scottish Court of Session in Addison v. Row confirm that the fast-fish, loose-fish requirement that a physical connection be maintained between whale and boat or crew had not been universally observed since the beginning of the Greenland fishery. ${ }^{145}$ Both sources further reveal that the practice of iron holds the whale was also observed in late eighteenth century Greenland and was not, as Ellickson speculates, an adaptation to hunting swifter and more combative sperm whales. ${ }^{146}$ In his 1778-79 work, Charles Theodore Middleton explained that in the Greenland fishery whales occasionally broke free from an attached line. ${ }^{147}$ "When this happens, however, if he is afterwards taken by the crew of another

137. Id.

138. Id.

139. Id.

140. DALRYMPLE, supra note 124 , at $179-80$.

141. Id. at 180 .

142. Id.

143. Id.

144. Id.

145. 2 Charles Theodore Middleton, A New and Complete System of Geography. CONTAINING A FULl, ACCURATE, AUTHENTIC AND INTERESTING ACCOUNT AND DESCRIPTION OF Europe, ASIA, AFriCA, AND AMERICA 22 (1778-1779); Addison v. Row, 3 Pat. App. 334, 338 (1792).

146. See MIDDLETON, supra note 145, at 22; Addison, 3 Pat. App. at 388; ElliCKSON, ORDER WITHOUT LAW, supra note 10, at 197-201; Ellickson, Hypothesis of Wealth-Maximizing Norms, supra note 10 , at 89-92.

147. MidDLETON, supra note 145 , at 22. 
ship," Middleton revealed, "he is returned to those who first wounded him, as that is known by the harpoon, which is always distinguished by a peculiar mark."148

\section{Addison v. Row Sounds the Judicially Imposed Death Knoll for Iron Holds the Whale: Different Views of Custom North and South of the River Tweed}

The practice of iron holds the whale was, as the previous section indicates, observed by some British whalemen in the Greenland fishery until at least the end of the eighteenth century. The Scottish decision in Addison v. Row provides a clear statement of iron holds the whale. ${ }^{149}$ When the matter was heard, however, on appeal before the House of Lords in 1794, the Scottish ruling was overturned. ${ }^{150}$ The House of Lords declared fast-fish, loose-fish to be the law governing disputes over contested whales. ${ }^{151}$ This pronouncement was a key moment in the rapid decline of the practice of iron holds the whale in the Greenland fishery.

In Addison v. Row, the Priscilla, an English ship in the Davis Strait, struck a whale and raised a flag to signal that it was fast. ${ }^{152}$ A nearby Scottish vessel, the Caledonia, lowered four boats to assist the Priscilla in capturing its prey. ${ }^{153}$ When the seriously injured whale emerged from its dive, the Caledonia promptly killed the animal that still bore the Priscilla's harpoon. ${ }^{154}$ Rather than return the whale as the crew of the Priscilla expected, the Caledonia kept the animal, arguing that it had broken free from its original attacker prior to being dealt the fatal blow. ${ }^{155}$ The Caledonia's claim was a clear invocation of the fast-fish, loose-fish rule that whales not in contact with its pursuers were free for the taking.

The Court of Session did not concur and instead advanced a rule very much akin to iron holds the whale. ${ }^{156}$ Lord President Campbell proclaimed that pursuant to the "general rule":

148. Id.

149. Addison, 3 Pat. App. at 334.

150. Id.

151. Id.

152. Id. Although the Davis Strait separates Baffin Island from the west coast of Greenland, British whalemen and government officials considered it part of the Greenland whalefishery. Government bounties for Greenland whaling included the waters between Davis Strait and Spitzbergen. 2 SCORESBY, AN ACCOUNT OF THE ARCTIC REgIONS, supra note 26, at 115, 491-505. Eighteenth and nineteenth century keepers of British whaling statistics frequently combined the fertile grounds of Spitzbergen and Davis Strait into a single Greenland or, as it was sometimes called, Northern fishery. Henry Munroe, Statistics of the Northern Whale Fisheries, from the Year 1772 to $1852,17 \mathrm{~J}$. OF THE STATISTICAL SOC'Y OF LONDON 34, 41-42 (1854). For a reliable general introduction to British whaling, see JACKSON, supra note 114.

153. Addison, 3 Pat. App. at 334.

154. Id.

155. Id.

156. Id. at 338 . 
[The whale] belongs to the first occupant, being naturally res nullius. But if I once seize upon the animal, and it breaks away from me, and I still continue in pursuit, I do not thereby lose my right as first occupant, so long as there are hopes of recovering it. There is no custom proved which can derogate from this general principle. . . . The boats of the Priscilla would have taken the whale if the Caledonia had never interfered. ${ }^{157}$

The Priscilla's victory was short-lived. The House of Lords viewed the law in starkly different terms. ${ }^{158}$ Lord Thurlow stated, "It is a settled point, that a whale being struck, and afterwards getting loose, is the property of the next striker who continues fast till she is killed."159 Applying fast-fish, loose-fish to the evidence adduced before the Scottish court, the House of Lords ruled that when the Caledonia struck the whale it was loose and free for the taking. ${ }^{160}$

Addison v. Row thereafter joined Littledale v. Scaith and Justice Buller's 1786 decision in establishing fast-fish, loose-fish as the universally accepted custom of the Greenland fishery in the minds of British jurists and lawyers. ${ }^{161}$ Subsequent decisions such as the 1805 ruling in Gale v. Wilkinson, which Scoresby and Melville both cited, solidified this perception. ${ }^{162}$ The question thus arises: was Lord Campbell mistaken in finding in the Court of Secession decision that fast-fish, loose-fish had not supplanted what he viewed as the general rule of honoring the rights of a first striker that remained in pursuit with reasonable prospects for success?

Middleton's geography text clearly established that Lord Campbell was correct that at least some Greenland whalemen in the late eighteenth century did not believe that a physical connection to a whale was required to constitute

157. Id. In Roman law, a thing was res nullius if it was subject to ownership, but was not, at present, owned. RICHARD WOODDESSON, LECTURES ON THE LAW OF ENGLAND 423 (1842).

158. Addison, 3 Pat. App. at 334.

159. Addison, 3 Pat. App. at 339.

160. Id. at 334 .

161. See Litlledale v. Scaith, 1 Taunt. 241 (1788); Law Intelligence, supra note 98, at 3.

162. For Gale v. Wilkinson, see TIMES (London) Dec. 24, 1805, at 3; MELVILLE, supra note 1, at 433-34; 2 SCORESBY, AN ACCOUNT OF THE ARCTIC REGIONS, supra note 27, at 323-24, 518-21. Scoresby supplied a report of the case of Gale $v$. Wilkinson as an appendix to his book. See 2 SCORESBY, AN ACCOUNT OF THE ARCTIC REgIONS, supra note 27, at 518-21. In Gale, a boat from the Neptune struck a whale at the edge of an ice field in the Spitzbergen fishery. Id. at 518 . The harpoon line being soon fully extended, the crew abandoned the boat for the safety of the ice and allowed the whale to carry it under the surface. Id. When the whale reappeared with the boat still attached, a second ship, the Experiment, arrived and, with the assistance of the Neptune's boats, captured the whale. $1 d$. at 518-19. The Neptune's expectation that the whale would be returned was dashed when the captain of the Experiment refused to even return the attached harpoons, lines, and boat. Id. at 519 . In the ensuing litigation in England, Lord Ellenborough ruled that the Neptune had lost possession of the whale when its crew abandoned the attached whaleboat. Id. at 520 . It did not matter what was attached to the whale. Id. The crucial issue was the contact between the whale and the crew of the Neptune. Id. Lord Ellenborough did direct that the boat be returned to the Neptune's owner. Id. at 521 . In the most famous part of the decision, the line and the harpoon were retained by the Experiment pursuant to the theory that the whale had obtained a sort of property right to this equipment that was transferred to the Experiment upon capture of the animal. Id. The law, while often lacking a sense of humor, is frequently amusing. 
possession. ${ }^{163}$ It is impossible, of course, to know the degree to which particular norms were practiced in Greenland. It is, however, possible to understand why Lord Campbell determined that fast-fish, loose-fish was not binding in Greenland and why the House of Lords disagreed. As described below, the power of the House of Lords to overturn the Scottish decision established the ascendancy of fast-fish, loose-fish and quickly erased the legal memory of iron holds the whale as a custom once observed in the Greenland fishery. ${ }^{164}$

\section{The Civil Law Tradition in Scotland}

The conflicting decisions rendered by the Scottish Court of Session and the House of Lords in Addison indicate some of the important differences between Scottish and English law in the late eighteenth century. While a contentious debate persists between legal historians as to the degree to which Scottish law is a mix of the civilian tradition and English common law, it is beyond peradventure that Roman law shaped the way courts north of the River Tweed viewed the creation of law. ${ }^{165}$ Roman law was never accepted, in full, as constituting the common law of Scotland. ${ }^{166}$ It did, however, form an intellectual foundation and a structure for Dalrymple, George Mackenzie, John Erskine, and the other so-called Institutional writers of the seventeenth and eighteenth centuries in their attempts to set forth the nature of Scottish law. ${ }^{167}$

The authority enjoyed by Roman law was, in large part, a product of the type of legal education open to aspiring Scottish lawyers prior to 1750.168 Educated mostly in France and later Holland, generations of Scottish law students returned home with a deep appreciation of Roman law and the civil law tradition. ${ }^{169}$ Erskine asserted in the posthumous 1805 edition of $A n$ Institute of the Law of Scotland that of "all the systems of human law which now exist, the Roman so well deserves the first place, on account of the equity of its precepts, and the justness of its reasonings." ${ }^{170}$ Erskine illustrated the extent to which his view was shared by his countrymen with the observation that the pre-1707 Estates of Parliament frequently justified legislation by

163. MidDleTON, supra note 145 , at 22 .

164. Addison, 3 Pat. App. at 339.

165. For an introduction to some of the differences between Scottish and English law in this period, see John W. Caims, Attitudes to Codification and the Scottish Science of Legislation, 1600-1830, 22 TUL. EUR. \& CIV. L.F. 1-78 (2007); W. D. H. Sellar, Scots Law: Mixed from the Very Beginning? A Tale of Two Receptions, 4 EDINBURGH L. REV. 3-18 (2000); J. T. Cameron, Custom as a Source of Law in Scolland, 27 MOD. L. REV. 306-21 (1964); Walker, supra note 158.

166. For the place of Roman law in Scotland, see Cairns, supra note 165, at 14-25.

167. Id. at 14-25; Walker, supra note 158, at 330-31.

168. Cairns, supra note 165 , at 4-5.

169. DAVID M. WALKER, THE SCOTTISH Legal SYSTEM: AN INTRODUCTION TO THE STUDY OF SCOTS LAW 80-81 (1963).

170. 1 JOHN ERSKINE, AN INSTITUTE OF THE LAW OF SCOTLAND, IN FOUR BOOKS. IN THE ORDER OF SIR GEORGE MACKENZIE'S INSTITUTIONS OF THAT LAW 9 (1805). 
declaring it conformable to Roman law. ${ }^{171}$ Roman law also provided guidance for situations not clearly governed by statutes or custom. The paucity of Scottish legislation, Erskine explained, further magnified the influence of Roman law. ${ }^{172}$

The importance of the civil law tradition in the development of Scottish law was not limited to substantive Roman law. Scottish legal scholars also developed a particular way of thinking about law and the resolution of legal problems foreign to those schooled in English common law. ${ }^{173}$ The civil law tradition-of which Roman law is the primary component-encourages its practitioners to grasp the large, foundational principles behind what might otherwise appear to be a jumble of disconnected statutes and customs. ${ }^{174}$ The law, understood in this way, is about deducing answers that advance, in Erskine's words, "an equal distribution of justice, on which the happiness of every society depends." 175 As the legal system deemed most steeped in justice, Roman law naturally provided an invaluable guide to moving from broad principle to a particular application. ${ }^{176}$

\section{E. Fennings v. Lord Grenville:}

The Elastic Application of Custom in English Law

English common law, on the other hand, was based in this period on the fiction that it gained much of its authority from immemorial usage. ${ }^{177}$ Provisions that make up the common law are, Blackstone famously remarked, customs whose origins must date to a "time whereof the memory of man runneth not to the contrary." 178 Evidence as to the customs that make up the common law of England is found in the reports of previous decisions rendered by generations of learned judges who, in their study of precedent, are "living oracles" of English law. ${ }^{179}$ An English judge is duty-bound to follow precedent in deciding a case even if the logic of the established custom is not immediately apparent. ${ }^{180}$ Blackstone indicated that only a precedent that was flatly absurd or unjust need not be followed. ${ }^{181}$ The truth, of course, is that the theoretical

171. Id. at 15 .

172. Id. at 1-22. For an introduction to some of the differences between Scottish and English law in this period, see Cairns, supra note 165; Sellar, supra note 165, at 3-18; Cameron, supra note 165, at 306-21. For the education of Scots lawyers, see Cairns, supra note 165, at 4-5.

173. Sellar, supra note 165 , at 13-15.

174. Id. at 15 .

175. 1 ERSKINE, supra note 170 , at 2.

176. I ERSKINE, supra note 170 , at 9.

177. E. K. Braybrooke, Custom as a Source of English Law, 50 MICH. L. REV. 71 (1951-1952).

178. 1 BLACKSTONE, supra note 17, at 67. See generally id. at 63-85 (discussing custom, precedents, and judges).

179. Id. at 69 .

180. Id.

181. Id. Cambridge professor Edward Christian countered in his comments appended to the 1793 edition of Blackstone's Commentaries that even flatly absurd or unjust provisions must be followed as 
rigidity of custom has always encouraged a rather elastic application of the concept. English jurists in the late eighteenth century-like many judges in common law jurisdictions today-were adept at distinguishing the facts in the case at bar from those in a case that set a troubling precedent to avoid an unfortunate result. Judges were also willing to consider practices of decidedly recent origins as custom. ${ }^{182}$

The problem of strictly applying the English common law notion of custom in a whaling dispute is well illustrated by the 1808 Common Pleas decision in Fennings v. Lord Grenville. ${ }^{183}$ In 1805, two English ships, the William Fennings and the Caerwent, were hunting for whales near the Galapagos Islands. ${ }^{184}$ The William Fennings, while killing a whale, struck a second whale. ${ }^{185}$ The boat's crew attached a small buoy, or drogue, to the second whale to slow its progress and mark its position for later capture. ${ }^{186}$ The Caerwent subsequently took up the chase and killed the whale. ${ }^{187}$ All agreed that pursuant to fast-fish, loose-fish, as practiced in the Greenland fishery, the Caerwent would be entitled to possession of the whale: the whale was not attached to the William Fennings and was, therefore, a loose fish. ${ }^{188}$ However, the owners of the William Fennings adduced testimony that in the Southern fishery - as the area around the Galapagos Islands was known - a different custom prevailed. ${ }^{189}$

Since its inception, the Southern fishery awarded one half of the whale to the party that affixed a drogue and one half to the whaler that killed the animal. ${ }^{190}$ Counsel for the Caerwent's owners acknowledged that this had once been the custom of the Galapagos, but argued that since 1792 the custom of most captains was to award the entire whale to the ship that actually captured it. ${ }^{191}$ Evidence also showed that the captain of the Caerwent was one of six masters who had agreed upon his arrival in the Galapagos in 1805 to follow the emerging custom that eschewed the sharing of whales. ${ }^{192}$ Chief Judge

properly constituted English law so long as they were in general accord with the longstanding principles of English law. Id. The remedy in such situations must be in Parliament. Id. at 70 .

182. Cameron, supra note 165 , at 308-10.

183. Fennings v. Lord Grenville, 1 Taunt. 241 (1808).

184. Id.

185. Id.

186. Id. Drogues used in the Southem fishery commonly consisted of pieces of wood attached to the lines. Granville allen Mawer, ahab's Trade: The Saga of South SEas Whaling 350 (1999).

187. Fennings, 1 Taunt. at 241.

188. Id.

189. Id. at $241-42$

190. Id. at 242.

191. Id. at $241-42$.

192. Id. at 242. The agreement referenced in Fennings has not survived, but for an example of an agreement by Galapagos whalemen from many nations providing that the first striker was not entitled to a portion of the whale from the vessel that ultimately dealt the fatal blow, see EDOUARD A. STACKPOLE, Whales \& DESTINY: THE RIVALRY BETWEEN AMERICA, FRANCE, AND BRITAIN FOR CONTROL OF THE SOUTHERN WHALE FISHERY, 1785-1825, at 388-89 (1972). 
Mansfield determined that as the captain of the William Fennings was not a party to that agreement, the Southern fishery custom of dividing the whale must be followed. ${ }^{193}$ Judge Chambre's concurrence advanced the importance of following custom in an area where the subjects of many nations engaged in commerce. ${ }^{194}$ Failure to abide by established customs would result in a sort of warfare between ships that might eventually extend to the nations of those involved. 195

While much of the judges' discussion in Fennings concerned whether the action was properly brought in trover, the arguments of counsel illuminated the gap between custom in theory and the way that custom shaped English substantive law. ${ }^{196}$ Counsel for the Caerwent argued in the alternative: either the practice of splitting whales in the Southern fishery did not constitute "a custom of a particular trade as to be binding in law" or if the practice was a custom, it was no longer followed. 197 Given the apparent disagreement between captains plying these waters as to established practice, the Caerwent suggested that the court apply the common law rule of ferae naturae. ${ }^{198}$ Not surprisingly, the Caerwent - as a second striker-argued that the common law honored the claim of the party with actual physical possession of the prey. ${ }^{199}$ Given the strict definition of custom as synonymous with common law, a reader might be excused for wondering what counsel meant when he suggested that, in the case of the Southern fishery, a custom was not always binding. Furthermore, if this treatment of ferae naturae was the common law-and, therefore, custom - why were other practices even under consideration? ${ }^{200}$

The reason for this confusion can be found in the difficult position imposed on English judges and lawyers by the strict declaration that the common law was custom. ${ }^{201}$ How could the common law evolve to accommodate new problems and rethink old issues if courts were bound to follow practices that dated back into the misty English past? The solution was to pay lip service to the theory that there was no such thing as a new general

193. Fennings, 1 Taunt. at $246-47$.

194. Id. at 248-49.

195. Id. at 248.

196. See id. at 241-46.

197. Id. at 242.

198. Id.

199. Id.

200. See id. Despite the court's determination that the existing custom favoring the William Fennings was applicable, a nonsuit was entered dismissing the action brought by its owners. Pursuant to English law, the owners of the two ships were deemed tenants in common in the whale. Tenants in common were often said to have a unity of possession. Joint tenants enjoy an equal right to possess the entire property held in common. The mistake made by the owners of the William Fennings was to bring this action in trover. An action in trover between tenants in common was only permitted when the common property had been destroyed. It was determined that killing a whale at sea and rendering its remains into oil constitutes preservation, rather than destruction. Id. at 245-46. In other fisheries where the custom did not call for the sharing of a whale trover was the preferred cause of action. See, e.g., Hogarth v. Jackson, 2 Car. \& P. 595 (1827).

201. See Cameron, supra note 165 , at $306-11$. 
custom, while recognizing the existence of fresh, limited customs that were subject to a different set of rules. ${ }^{202}$ A local custom was one that supplanted a general custom in a particular region through observance from time immemorial or, at least, for a long time. ${ }^{203}$ The theory appeared to be that such local customs shared with general customs the same hoary past that demanded recognition as law. ${ }^{204}$ Unlike general customs that existed throughout the realm, it was possible for courts to recognize local customs that had not previously come to the attention of courts or legal scholars despite their antiquity. 205

The court's acknowledgement of local custom was not by itself, however, a sufficient mechanism for change. ${ }^{206}$ What status should courts give to the often dynamic and ever evolving practices observed in particular trades or businesses that were essential to the British economy? Courts termed such recent norms and practices "usages," and while denying the power of custom to change law they allowed usages to be read into contracts between participants in a particular trade so long as they did not run counter to established law. ${ }^{207}$ The recognition of local custom and usage was useful, but did not allow courts the desired room for innovation. ${ }^{208}$

The ultimate solution was a blending of the concepts of general custom, local custom, and usage. Courts grew accustomed long before Fennings to permitting even usages to create law. ${ }^{209}$ Counsel for the Lord Grenville manifested a degree of frustration with the traditional common law theory as to how laws come into being by his observation-supported in true English fashion with applicable precedent - that in resolving the case at bar it was immaterial whether the practice in the Southern fishery "be called an universal agreement in the trade, or an usage, or a custom."210 For the Lord Grenville's counsel, the important issue was whether "this practice as in the nature of a law, ... possesses the quality so essential to that character, of being highly reasonable."211 Judge Chambre's opinion shared much of counsel's pragmatism in his concern that whatever rule was adopted needed to prevent the international cast of participants in the Southern whalefishery from sparking warfare at sea. ${ }^{212}$

202. Id. at $306-09$.

203. Id. at 307.

204. Id. at $306-08$.

205. Id. at 307 .

206. Id. at 307-09.

207. Id. at 308 .

208. Id. at 306-08. For an example of how an English court viewed a recently developed usage in a particular business as altering the terms of an insurance policy, see Noble v. Kennoway, 2 Dougl. 510,99 Eng. Rep. 326 (1780).

209. See Cameron, supra note 165 , at 306-11.

210. Fennings v. Lord Grenville, 1 Taunt. 244 (1808).

211. Id. at 244.

212. See id. at 248. 
"The greatest of all legal fictions," English historian E. P. Thompson concluded, "is that the law evolves, from case to case, by its own impartial logic, true only to its own integrity, unswayed by expedient considerations." 213 To Thompson's observation one might add that the core explanation for how law is created in English common law is also a fiction motivated by a healthy dose of expediency.

\section{F. The Roman Law of Ferae Naturae Trumps Custom in Scottish Law}

The arguments of counsel before the Court of Session and President Judge Campbell's ruling in Addison v. Row illustrate how differently Scots viewed custom as a mechanism for change. ${ }^{214}$ Counsel for both ships presented arguments straight out of Justinian's Digest that would have been immediately recognizable to anyone who had studied Roman law since its revival in eleventh-century Bologna. ${ }^{215}$ Drawn from Book 41, title 1 of the Digest, the counsels for the two ships debated at what point in the pursuit of a wild animal a first striker was deemed to possess its quarry. ${ }^{216}$

Counsel for the Caledonia asserted that fast-fish, loose-fish was the custom of the fishery and should be honored because it accorded with the general principles of ferae naturae, the Roman law concept that gave ownership to the party that gained actual possession of the beast. ${ }^{217}$ The Priscilla countered that the requirement of physical control was an antiquated position, suitable to a more primitive notion of property rights. ${ }^{218}$ The modern rule, favored by more recent Roman lawyers, credited the first striker and was based on the advanced notion that the possession of property was more properly an act of the mind than a race to hold an animal. ${ }^{219}$ President Judge Campbell, in explaining his decision for the Courts of Session, first considered which view of possession represented "the general rule."220 Citing from the Digest, Campbell agreed with the Priscilla that the recent trend was to loosen the degree of possession needed to secure a wild animal. ${ }^{221}$ "There is no custom proved," Campbell continued, "which can derogate from this general principle." 222

The reader is left to wonder whether Campbell was saying that the Caledonia failed to demonstrate that fast-fish, loose-fish was the custom of Greenland or that no custom was competent to overcome a general principle of

213. E. P. THOMPSON, WhigS AND HUNTERS: THE ORIGIN OF THE BLACK ACT 250 (1975).

214. See Addison v. Row, 3 Pat. App. 334 (1792).

215. Id.

216. Id. at 337 .

217. Id. at 338-39.

218. Id. at 337 .

219. Id.

220. Id. at 338 .

221. Id.

222. Id. 
Roman law. The likely answer can be found in the Scottish approach to custom. Erskine explained that, following the Roman model, Scots laws were either written or unwritten. ${ }^{223}$ Written law as set forth in statutes clearly carried the express authority of the duly constituted officials. ${ }^{224}$ The unwritten law of Scotland was customary and derived its binding status from the tacit approval of the legislature. ${ }^{225}$ This customary law -also referred to as the common law of Scotland-consisted of "ancient usages ...., whether derived from the Roman law, the feudal customs, or whatever other source."226

Erskine indicated that some usages, such as primogeniture or the widow's terce, were so ancient and accepted that no proof of their status was necessary. ${ }^{227}$ Other customs, of a more recent accretion, required evidence of the "antiquity and universality" of their usage. 228 When Scots lawyers spoke of a custom being of immemorial usage, however, they did not, like their English brethren, imagine a practice so old that its origins could not be discerned. ${ }^{229}$ Instead, a custom in Scots law could slowly gain acceptance, requiring no particular length of existence or number of usages to be deemed valid. ${ }^{230}$ As Erskine explained, "some things require in their nature longer time, and a greater frequency of acts, to establish them, than others."231

While the absence of a prescribed period of time before a practice could become a custom might seem to indicate an easier path to establishment as law in Scotland, the opposite was true. ${ }^{232}$ Recall that in England only a local custom could create a new law. ${ }^{233}$ All general customs were already part of the common law. ${ }^{234}$ If a local custom was clearly at odds with the universal custom, an English legal theorist was not troubled, as both practices had been blessed with the imprimatur of immemorial usage. ${ }^{235}$ By permitting both universal and local customs to evolve slowly, Scots law required that its customs be tested for accordance with the core principles of the law. ${ }^{236}$ Antiquity could not save a custom that violated the accepted common law of Scotland which, as we have seen, was heavily dependent upon Roman Law. ${ }^{237}$

The differences between Scottish and English practice in this regard can be seen in the latter's embrace of the principle- set forth in the maxim

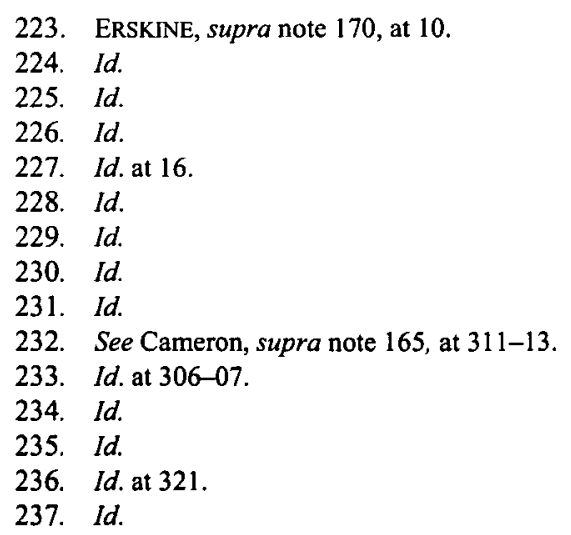


communis error facit jus - that a long-held mistake as to the substance of the common law should be permitted to stand even after its discovery. ${ }^{238}$ The Scots, pledged to a common law that best reflected the aspirations of society, would quickly act to correct any such errors. ${ }^{239}$ The practical result of this distinction was that Scots jurists such as Campbell were reluctant to look to customs or usages for guidance. Why risk adopting a new way of looking at a problem when the situation was already covered by Roman law? Despite the theoretical acceptance of custom as a source of new law, legal historian J. T. Cameron has remarked that there exists "no single clear case of a customary rule being accepted as law by a Scottish court." 240

Accordingly, when Judge Campbell was faced with the facts in Addison v. Row, he turned to the well established Roman law discussion of ferae naturae, not the norms of the whaling industry. ${ }^{241}$ It was, of course, true that fast-fish, loose-fish and iron holds the whale embodied the competing arguments set forth in Justinian's Institutes. ${ }^{242}$ Although Judge Campbell undoubtedly recognized the similarities, his inclination was not to find a new custom, but to determine which rule of whaling was, in principle, the most just. ${ }^{243}$ That he chose to use the language of the Roman law and not that of immemorial usage is not surprising.

Confronted with the same situation, although framed by counsel in accordance with English common law, the House of Lords sought to determine how whalemen resolved such arguments. ${ }^{244}$ For the House of Lords, the stakes were not particularly high. Whaling was a very particular industry. Despite its importance to the British economy, giving a whaling practice legal approval would have little role in shaping the law in other areas of commerce. To a Scottish judge the issue was not just how whalemen operated in a remote part of the world; it was about a higher principle of justice.

After the House of Lords declared fast-fish, loose-fish to be the custom of Greenland whaling, it enjoyed a long run in British courts and legal treatises as the largely unchallenged law of whaling. The competing idea of iron holds the whale appears to have died out among Greenland whalemen after Addison established fast-fish, loose-fish as the legal standard. Yet the idea that a first striker in pursuit deserved some consideration abided in the icy waters of the Greenland fishery. As Scoresby made clear, there was something unseemly

238. Cameron, supra note 165 , at 321 . For a brief discussion of communis error facit jus, see Herbert Broom, A SElection of Legal MaXims, Classified aNd Illustrated 51 (1845).

239. Cameron, supra note 165 , at 321 .

240. Id. at 313 .

241. Addison v. Row, 3 Pat. App. 334, 338 (1792).

242. JUSTINIAN'S INST. 2.1.13 (533).

243. See Addison, 3 Pat. App. at 338.

244. Id. at 339-40. 
about a first striker, in active pursuit, losing a whale to an opportunistic interloper. ${ }^{245}$

\section{BRITISH COURTS SHAPE WHALING CUSTOMS}

By 1820 , the line of British cases beginning with Addison had established fast-fish, loose-fish as the property law of whaling. In the $1820 \mathrm{~s}$, British courts began to expand the definition of fastness to include whales that were not attached to a boat by harpoon and rope. This expansion did not reflect changes in how whalemen operated at sea, but rather the desire of courts to reach results that seemed fairer to a first striker whose crew had expended much effort in the chase. British lawyers and judges found that use of the emerging action of interference with trade allowed them to reach a desired result while maintaining the custom of fast-fish, loose-fish.

In Hogarth v. Jackson, the court expanded the fast-fish, loose-fish definition of fastness to include whales swimming free of the first striker's harpoons but entangled in lines attached to his boat. The judge explained that a first striker so situated should prevail over an intervener so long as he had a reasonable expectation of taking the whale prior to the improper interference of the second boat. The court acted in response to changes in the custom of the fishery and the decision of plaintiff's counsel to include a count of the newly emerging tort of interference with trade.

\section{A. Hogarth v. Jackson: The Requirement that a Whale be Fast Gets a Bit Looser}

On September 21,1826, the Old Middleton spied a whale while standing off the coast of Greenland in company with the Andrew Marvel and the Resolution. ${ }^{246}$ A boat dispatched from the Old Middleton succeeded in affixing a harpoon, and the whale - as was often the case-swam off at a fast rate of speed with the attached boat in tow. ${ }^{247}$ Later explaining that it believed the whale to be loose, the crew of the Andrew Marvel took up the chase, managing to strike and kill its target. ${ }^{248}$ Whether the Andrew Marvel had been in a position to observe the Old Middleton's original assault is unclear. It is likely, in any event, that what began as an attempt to assist the Old Middleton changed when it became apparent to the Andrew Marvel that its competitor's line had come loose from the harpoon. ${ }^{249}$

245. 2 SCORESBY, AN ACCOUNT OF THE ARCTIC REGIONS, supra note 27, at 327.

246. For the various sources for Hogarth v. Jackson, see 2 Car. \& P. 595 (1827), 1 Moo. \& Malk. 58 (1827), TIMES (London), Mar. 2, 1827, at 3, MORNING CHRONICLE (London), Mar. 2, 1827. It is not clear if the Resolution involved in this matter was the same ship captained by Scoresby in 1811 and 1812. Scoresby served as the master of other vessels beginning in 1813. ARCTIC WHALING JOURNALS OF WILLIAM SCORESBY, supra note 26 , at xxiii.

247. Hogarth, TIMES (London), Mar. 2, 1827, at 3.

248. Id.

249. See id. 
In the London Court of Common Pleas, counsel for the Andrew Marvel cited Fennings $v$. Lord Grenville for the time-honored proposition that a whale remained fast only so long as the connection between the first striker's boat and the affixed harpoon remained intact. ${ }^{250}$ The Old Middleton countered that the custom of fast-fish, loose-fish had evolved in the nearly twenty years since Fennings was decided. ${ }^{251}$ The evidence presented at trial proved to the court, and forced the Andrew Marvel to concede, that in the Greenland fishery a whale was now considered fast--even absent an attached harpoon-if it was entangled in the line which remained in control of the original striker. ${ }^{252}$ The jury found that the whale had remained fast and rendered a verdict for the Old Middleton. 253

While the change in custom set forth in Hogarth $v$. Jackson-as this case was captioned-was slight, it reveals a fluidity in whaling customs not readily apparent in many scholarly treatises that continued to cite Fennings as the prevailing standard long after the British had largely abandoned the trade. ${ }^{254}$ The impetus for this incremental alteration in the custom was likely the feeling of most whalemen that making the continued attachment of the harpoon determinative was, as Scoresby would have agreed, unfair to the first striker. ${ }^{255}$ That English courts-always concerned with following the lead of whalemen in setting the customs in an international industry-would have been sensitive to changes at sea is not surprising. ${ }^{256}$ What is curious is the degree to which trial judges and lawyers seemed to be leading the whalemen, pushing the law towards a standard that honored a first striker that remained in pursuit of a detached whale. Although it may be that jurists were simply reacting to evidence adduced from whalemen that was not preserved in the reported decisions, the evidence from other trials in the same period does not indicate that whalemen were moving in this direction. ${ }^{257}$

250. Hogarth, 2 Car. \& P. at 596.

251. Id.

252. Hogarth, 1 Moo. \& Malk. at 58.

253. Hogarth, 2 Car. \& P. at 596.

254. For post-Hogarth legal treatises that continued to state the law of whaling as set forth in

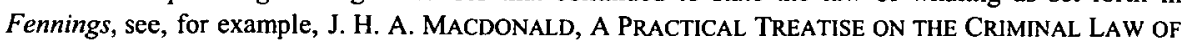
SCOTLAND 24 (1867); 1 Hugh BarClay, A Digest OF THE LAW OF SCOTLAND 375 (1852-1853); GEORGE LYON, ELEMENTS OF SCOTS LAW IN THE FORM OF QUESTION AND ANSWER: WITH A COPIOUS APPENDIX CONTAINING FORMS OF WRITINGS FOR THE PURPOSE OF REFERENCE AND ILLUSTRATION 3-4 (1832).

255. See 2 SCORESBY, AN ACCOUNT OF THE ARCTIC REgIONS, supra note 27, at 327.

256. See, e.g., Fennings v. Lord Grenville, 1 Taunt. 248 (1808).

257. For two other whaling cases from this period, see Hutchison v. The Dundee Union Whale Fishing Company, reported in ALEXANDER PETERKIN, WHALE Fishery: REPORT OF THE TRIAL BY JURY, JOHN HUTCHISON, ESQUIRE, AND OTHERS, AGAINST THE DUNDEE UNION WHALE FISHING COMPANY (1830), and also in JOSEPH MURRAY, REPORTS OF CASES TRIED IN THE JURY COURT, AT EDINBURGH, AND ON THE CIRCUIT, FROM NOVEMBER 1828 TO JULY 1830, BOTH INCLUSIVE 162-65 (1831); and Nicoll v. Burstall covered in TIMES (London) Feb. 27, 1834, MORNING CHRONICLE (London) Feb. 27, 1834, HULl PACKET (Hull) Mar. 7, 1834, and in NORTH WALES CHRONICLE (Bangor, Wales) Mar. $11,1834$. 
Fundamental uncertainty as to what precisely transpired at court is endemic to Anglo-American law in this period. Reports of cases were produced privately for profit and were not subject to court approval. ${ }^{258}$ Although the reporters were members of the bar, the quality of their work varied greatly. ${ }^{259}$ Only a small percentage of trials were reported and the criteria for inclusion in the published volumes were rarely made clear. ${ }^{260}$ One early nineteenth century reporter, John Campbell, famously remarked in his autobiography that he suppressed decisions of Lord Ellenborough that he deemed "inconsistent with former decisions or recognised principles."261 Whether Lord Ellenborough should have been grateful-as Campbell bragged—is unclear as the "bad Ellenborough law" has not survived. ${ }^{262}$ The problem of selective and possibly incompetent reporting was not new. Blackstone lamented that since the early sixteenth century private reporters "through haste and inaccuracy, sometimes through mistake and want of skill, have published very crude and imperfect (perhaps contradictory) accounts of one and the same determination."263 The reports produced for the trial of Hogarth $v$. Jackson illustrate this problem of interpreting competing reports that confronted contemporaries and has vexed later scholars.

The discussion of Hogarth presented in Carrington \& Payne's Nisi Prius Reports was brief and unequivocal. ${ }^{264}$ It explained that the custom of fast-fish, loose-fish set forth in Fennings had been changed so that a whale remained fast "whether the harpoon continues in the body or not, if the fish is attached by any means, such as the entanglement of the line, or other cause, to the boat of the party first striking it, so that such party may be said to have the power over it [the line] . . ."265 It was also reported that Chief Judge Best opined that this new custom represented an improvement in that it was not always easy to determine in the water whether a harpoon remained affixed. ${ }^{266}$

A perceptive reader of The Times blessed with a good memory might well have reviewed Carrington and Payne's report of the Hogarth trial with some confusion. ${ }^{267}$ The Times account, printed the day after the trial, explained that the custom had long been that when a whale is "struck by a boat, in such a manner that there shall be little doubt of the crew being ultimately able to kill it, it is considered the property of that boat." ${ }^{268}$ The custom of fast-fish, in The

258. See James Oldham, Law-making at Nisi Prius in the Early 1800s, 25 J. LEGAL HIST. 221, 22325 (2004).

259. See id.

260. Id. at 223 .

261. Id.

262. Id.

263. 1 BLACKSTONE, supra note 17 , at 71 .

264. See Hogarth v. Jackson, 2 Car. \& P. 595, 595-96 (1827).

265. Hogarth, 2 Car. \& P. at 596.

266. Id.

267. See Hogarth v. Jackson, TIMES (London), Mar. 2, 1827, at 3.

268. Id. 
Times' telling, sounded very much like the law advanced by Judge Campbell in Addison v. Row. ${ }^{269}$ While it is tempting to dismiss The Times account as the product of a reporter unskilled in the ways of the law, the version of Hogarth contained in Moody \& Malkin's Nisi Prius Reports suggests that the newspaper's coverage of the case-while misleading as to the custom of the fishery-was not entirely inaccurate. ${ }^{270}$

Moody and Malkin framed the argument between the parties in different terms than those presented by their competitors Carrington and Payne. ${ }^{271}$ In Carrington and Payne's account, the Andrew Marvel argued in favor of the Fennings custom, while the Old Middleton convinced the court that a new standard no longer required that the harpoon remain in the whale and attached to an entangled line. ${ }^{272}$ Moody and Malkin, on the other hand, indicated that the Andrew Marvel conceded that the harpoon's position was not determinative and that the dispute between barristers centered on the degree of control the first striker must retain over the line in which the whale was entangled. ${ }^{273}$ The Old Middleton, as first striker, maintained that a whale was fast if the rope remained in the control of the boat and "was any how attached to the fish." 774 The Andrew Marvel countered that a whale was not-pursuant to the new custom - entangled "unless she [the whale] were so fast in the rope as to give the first strikers the same power over her as if the harpoon continued fixed."275

The difference in how the competing reporters presented the argument may be the result of Carrington and Payne providing the initial arguments of counsel. ${ }^{276}$ As Moody and Malkin indicated, the Andrew Marvel at some point conceded that the custom had changed. ${ }^{277}$ Perhaps it was at this point that the defendant's position changed to reflect the obviously compelling evidence of a new practice and became that presented by Moody and Malkin. The most interesting difference between the two reports, however, was in the role assigned to Chief Judge Best. In Carrington and Payne's account, Best simply gave his imprimatur to the change in custom. ${ }^{278}$ By contrast, the judge emerges in Moody and Malkin's telling as a full participant in shaping custom into law. ${ }^{279}$ Best expressed his view that the Old Middleton was fast if the custom was "understood to extend to all cases where the whale was so far entangled in the rope of the first strikers, that they might thereby have a reasonable

269. See Addison v. Row, 3 Pat. App. 334 (1792).

270. See Hogarth v. Jackson, 1 Moo. \& Malk. 58 (1827).

271. See id.

272. Hogarth v. Jackson, 2 Car. \& P. 595 (1827).

273. Hogarth, 1 Moo. \& Malk. at 58.

274. Id. at 58 .

275. Id. at 58 .

276. See Hogarth, 2 Car. \& P. at 595.

277. Hogarth, 1 Moo. \& Malk. at 58.

278. Hogarth, 2 Car. \& P. at 596.

279. See Hogarth, 1 Moo. \& Malk. at 59. 
expectation of securing her." 280 The judge appeared to have simply decided that the test should include an assessment of the first striker's prospects for capturing the whale. ${ }^{281}$

Given the concordance between the accounts of The Times and Moody and Malkin, it seems likely that Chief Judge Best did indeed interject the idea that the likelihood of the first striker completing capture of a whale-absent intervention-was relevant to deciding such disputes. ${ }^{282}$ As reporters, Moody and Malkin appear not only to have recorded Judge Best's legal analysis, but also to have relaxed the initial boat's burden of proof. ${ }^{283}$ In the printed marginalia common in legal reports of this era, Moody and Malkin characterized the custom as entitling the first striker to a whale "though his harpoon be detached from the line when the second striker strikes, if the fish be so entangled in his line that he might probably have secured her without the interference of the second striker."284 Moody and Malkin's "might probably" would seem to require a lesser probability of success than the "reasonable expectation" ascribed directly to Judge Best. The role of Moody and Malkin in shaping-or at least attempting to shape-whaling law can also be seen in their decision to include as part of their Hogarth report a discussion of Skinner $v$. Chapman, which, as the next Part indicates, raised the likelihood of the first striker capturing a whale in the absence of interference from a competitor as a factor in awarding contested cetaceans. ${ }^{285}$

\section{B. Skinner v. Chapman: When a Loose Fish Remains Fast}

In Skinner v. Chapman, heard at the 1827 York Lent Assizes, a boat belonging to the Phoenix lanced a whale fast to the Harmony's harpoon and line. ${ }^{286}$ While the lance did nothing to assist in the capture of the whale, it did agitate the animal, causing it to break free of the harpoon. ${ }^{287}$ The Phoenix argued at trial that it subsequently harpooned what was then a loose target. ${ }^{288}$ The first striker countered that the second boat's harpoon was friendly in that it had been affixed prior to the moment when the whale's violent movements sundered the connection with the harpoon and line. ${ }^{289}$ Moody and Malkin

280. Id. (italics in original).

281. See id.

282. See Hogarth v. Jackson, TIMES (London), Mar. 2, 1827, at 3, 1 Moo. \& Malk. at 59.

283. See Hogarth, 1 Moo. \& Malk. at 58.

284. Id. at 58 .

285. See id. at 59 .

286. Skinner v. Chapman, 1 Moo. \& Malk. 59 (1827). The account of the trial in The Leeds Mercury appears to be largely a recitation of the argument made by the Harmony's counsel. LEEDS MERCURY (Leeds), Apr. 7, 1827. The newspaper does support Moody and Malkin's discussion of the finding of the jury; stating that the use of a lance to free the whale from the Harmony's harpoon was "a wrongful act" and that the Harmony would have taken the bowhead if the Phoenix had not interfered. Id.

287. Skinner, 1 Moo. \& Malk. at 59.

288. Skinner, 1 Moo. \& Malk. at 59, LEEDS MERCURY (Leeds), Apr. 7, 1827.

289. Skinner, 1 Moo. \& Malk. at 59, LEEDS MERCURY (Leeds), Apr. 7, 1827. 
stated that Judge Bayley charged the jury that if they determined that the first striker's harpoon had already come loose when the second iron was affixed, they must then decide "whether the plaintiffs [first striker] could have secured the fish if the lance of the defendants had not been struck."290 To this instruction, Judge Bayley added that it was his belief that if a whale had been successfully struck and an unsolicited party "does an act which prevents the first striker from killing it, and then kills it himself, he kills it, not for his own benefit, but for that of the first striker."291

There is, however, no evidence that whalemen in Greenland were developing a custom in this period that included any such calculation of the first striker's likelihood of success absent interference. Counsel in the 1830 Scottish case Hutchison v. Dundee Union Whale Fishing Company, for example, made no reference to the probability of capture even though Hogarth and Skinner were cited as precedent. ${ }^{292}$ Witness testimony in Hutchison, summarized in a thirty-four-page pamphlet reporting the trial, makes clear that the questions of the advocates were not directed at the first striker's prospects absent the interference of another vessel. ${ }^{293}$

Similarly, in Nicoll v. Eurstall, tried before the Court of Exchequer in 1834, The Times intimated that the rule in Fennings was still being followed in the Greenland fishery. 294 "The rule of the whale fishery," reported The Times, "was, that if the crew of any ship fix the harpoon into the whale and fasten it by their line to their boat, the crews of other vessels are not allowed to interfere with that whale, excepting indeed with the view of offering assistance."295 While the Nicoll court pointed to the necessity of an affixed harpoon, it also added-reflecting, perhaps, the Skinner decision-that an intervener cannot gain from preventing a first striker from killing a whale to which it was fast. ${ }^{296}$

\section{Interference with Trade}

If whalemen plying the waters of the Greenland fishery were not particularly concerned with the first striker's probability of capturing a whale, why were the judges in Hogarth and Skinner? The key to resolving this question can be found in Carrington and Payne's account of Hogarth. Whereas Moody and Malkin indicated that the cause of action was in trover, Carrington and Payne revealed that, in addition to trover, " $[\mathrm{t}]$ he declaration charged the

290. Skinner, 1 Moo. \& Malk. at 59.

291. Id. at 60 .

292. See MURRAY, supra note 257 , at 162-65.

293. See PETERKIN, supra note 257 , at 1-34.

294. See Nicoll v. Burstall, TIMES (London) Feb. 27, 1834; see also Nicoll v. Bursall, MORNING Chronicle (London) Feb. 27, 1834, Hull PaCket (Hull) Mar. 7, 1834, NorTh Wales Chronicle (Bangor, Wales) Mar. 11, 1834.

295. Nicoll, TIMES (London), Feb. 27, 1834.

296. See Nicoll, Times (London) Feb. 27, 1834, MORNING ChroniCle (London) Feb. 27, 1834, Hull PACKet (Hull) Mar. 7, 1834, NoRTH WALES ChroniCle (Bangor, Wales) Mar. 11, 1834. 
defendants with having interrupted the plaintiffs in killing a whale."297 According to an influential guide for practitioners in the period, a succesful action in trover required that the plaintiff prove "a property in himself" in the object of the dispute, "a right to the present or absolute possession of them," and that the defendant converted the property for his own use or refused a demand that the item be returned. ${ }^{298}$ Ownership or actual possession was not required. ${ }^{299}$ It was sufficient if the plaintiff had "a right of present possession, which the Plaintiff may immediately take if he pleases." 300 Trover proved to be a convenient cause of action for whaling disputes where an attached first striker did not actually possess the whale, but had a present possessory interest that the law was willing to recognize.

Trover was not, however, an action that could be maintained if the plaintiff's right was deemed to be one of future possession. ${ }^{301}$ In bringing the action in Hogarth, counsel for the Old Middleton likely reasoned that if the court failed to accept the new custom which honored an entangled whale absent an affixed harpoon as fast, his client would not prevail. Accordingly, the Old Middleton needed to state a cause of action that was not based on the level of possession required in trover or by the custom of the fishery. As Carrington and Payne reported, the Old Middleton also claimed that the Andrew Marvel had "interrupted the plaintiffs in killing a whale." 302 What the Old Middleton had set forth was a claim based not on their present possession of the whale, but on their right to continue pursuit of the whale without the interference of another party. ${ }^{303}$ The Old Middleton's rights, pursuant to this cause of action, were limited. ${ }^{304}$ It had the right to chase the whale without obstruction until it either succeeded in killing the animal or it no longer was in a position where capture appeared likely. ${ }^{305}$

This alternative cause of action - what British courts would later designate the tort of interference with trade, profession, or calling-was not well established in the $1820 \mathrm{~s}^{306}$ In the first decades of the twentieth century, legal

297. Hogarth v. Jackson, 2 Car. \& P. 595 (1827).

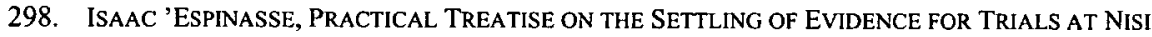

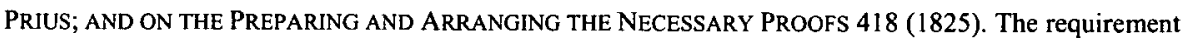
in trover that a plaintiff be in a position to immediately take possession of a disputed object does not seem to have ever been strictly enforced in whaling cases where a first striker's ability to take immediate possession was often questionable. The concept of fastness seems to have been used as conclusive evidence of a right to immediate possession.

299. Id.

300. Id. at 432 .

301. Id. at 418,432 .

302. Hogarth v. Jackson, 2 Car. \& P. 595 (1827).

303. Id. at 595.

304. See id.

305. See id.

306. Hazel Carty, Unlawful Interference with Trade, 3 LEGAL STUD. 193 (1983); G. A. Owen, Interference with Trade: The Illegitimate Offspring of an Illegitimate Tort?, 3 U. MONASH L. REV. 41 (1976-1977). 
scholars argued whether the tort was a late nineteenth century development or one of more ancient standing. ${ }^{307}$ Without recounting the specifics of this scholarly tussle, which seems to have had more to do with contemporary British labor relations law than a conscientious dispute over the historical development of a cause of action, there were numerous cases available in the 1820 s that at least suggested that a cause of action could be successfully brought to remedy tortious interference with a plaintiff's trade. ${ }^{308}$ The most famous of these cases was the 1707 matter of Keeble $v$. Hickeringill. ${ }^{309}$

In Keeble v. Hickeringill, the plaintiff, Keeble, had a decoy pond on his property that attracted ducks for capture. ${ }^{310}$ The neighbor, defendant Hickeringill, twice fired guns from his own property seeking to scare away Keeble's ducks. ${ }^{311}$ Keeble brought an action alleging that Hickeringill had interfered with his ability to gain a profit from his decoy pond. ${ }^{312}$ Hickeringill countered that Keeble did not own the ducks on his property and therefore did not have a cause of action. ${ }^{313}$ The court agreed that Keeble did not own the ducks, but pointed out that the action was not brought to recover property. ${ }^{314}$

Instead, the court held that Keeble had the right to enjoy the benefits of his decoy pond, free from the malicious interference of his neighbor. 315 "He that hinders another in his trade or livlihood," Chief Judge Holt explained, "is liable to an action for so hindering him." 316 The court hastened to add that Keeble's rights would not have prevented Hickeringill from exercising his concomitant privilege of building a decoy pond on his own property. ${ }^{317}$ In the context of a whale capture dispute such as Hogarth, a first striker who was not fast to a whale, but had wounded his quarry, had a limited possessory interest in the whale so long as he maintained the chase with the prospect of success. Similarly, Keeble had a limited sort of possession in ducks while they were on his property. 318

307. See generally 1 THOMAS ATKINS STREET, Foundations OF LEgAL LiABILITY: A PRESENTATION OF THE THEORY AND DEVELOPMENT OF THE COMMON LAW 347 (1906) (discussing the history of interference with trade and the relevant cases); Sarat Chandra Basak, Principles of Liability for Interference with Trade, Profession or Calling, 27 L. Q. REv. 290 (1911).

308. See Basak, supra note 307 , at 303-305.

309. Keeble v. Hickeringill, 3 Salk. 9, 91 Eng. Rep. 659 (1707). See generally Benjamin L. Fine, An Analysis of the Formation of Property Rights Underlying Tortious Interference with Contracts and Other Economic Relations, 50 U. CHI. L. REV. 1116 (1983) (providing a helpful discussion of the place of Keeble and the British whaling cases in the development of economic torts).

310. Keeble, 3 Salk. at 9-10.

311. Id.

312. Id.

313. Id.

314. Id.

315. Id.

316. Keeble v. Hickeringill, 11 East. 574, 575 (1707).

317. Id.

318. Similarly, in Tarleton v. $M^{\prime}$ Gawley, the plaintiff prevailed against a defendant who fired weapons from a ship off the coast of Africa to scare away his potential trading partners. 170 Eng. Rep. 153 (1793). In the celebrated case of Young $v$. Hichens, the plaintiff cast a seine around a shoal of 
While Skinner was, according to Moody and Malkin, brought in trover, it is very likely that there was an additional count of interference with trade. If the action was based solely on trover, Judge Bayley's instruction to the jury that they consider the likelihood of the first striker securing the whale absent the interloper's lance thrust would not be legally relevant. ${ }^{319}$ In trover, the first striker's possession, and therefore legal right to the whale, was conclusively established by the connection from the fish to the boat. ${ }^{320}$ Once this was established, the actual prospects of capturing the whale were irrelevant. It did not matter, for example, that at the moment after the intervener sank its harpoon into a whale the first striker's boat lost its line in a spectacular collision with ice that all witnesses agreed could be foreseen moments before its actual occurrence. The whale, in these circumstances, belonged to the first striker and the second boat's harpoon was deemed friendly. ${ }^{321}$

\section{CONCLUSION}

In recognizing the Greenland fishery custom of fast-fish, loose-fish, British courts simply adopted whaling custom in determining the moment and means by which possession vested in trover actions involving whales. The likelihood of capture was interjected by attorneys and discussed by judges only because it was relevant to interference with trade, a cause of action governed by principles different from those at work in fast-fish, loose-fish. Although British whalemen in Greenland never abandoned the underlying principles of fast-fish, loose-fish, the idea that the prospects of a boat's ultimate success was worthy of some consideration was not entirely antithetical to the men who practiced the whaling trade. ${ }^{322}$ Scoresby's belief that his father was entitled to the bowhead taken by the Resolution in the summer of 1812 reflected the same notion of fairness at work in the tort of interference with trade. ${ }^{323}$ It also explains the numerous times captains agreed among themselves at sea, without strict

mackerel. 115 Eng. Rep. 228 (1844). The fish were surrounded by the net with the exception of a seven to ten fathom opening at which was stationed two of the plaintiff's boats to rile the water and discourage escape. Id. A boat belonging to the defendant took advantage of the opening, entered the enclosure, and successfully cast its own seine within that of its competitor. Id. Arguing that he was in possession of the mackerel and would have, but for the defendant's actions, delivered the catch safely to shore, the plaintiff brought an action in trespass to recover the value of the fish. Id. The court acknowledged that the plaintiff was on the verge of taking possession of the mackerel and that, absent the defendant's interference, "it was in the highest degree probable" that capture would have been completed. This was not, however, sufficient to constitute the requisite degree of "custodia or occupation" to prevail at trespass. The plaintiff's actual power over the fish must, instead, be shown. Young v. Hichens, 1 Dav. \& Mer. 598 (1844). Lord Denman, as Benjamin Fine has recognized, opined that the plaintiff might have prevailed had a different cause of action been pursued. Fine, supra note 309 , at $1127-28$. It seems likely that Lord Denman had an interference tort in mind. See id.

319. See Skinner v. Chapman, 1 Moo. \& Malk. 59 (1827).

320. See $i d$.

321. See id.

322. See ARCTIC WhaLING JOURNALS OF WILlIAM SCORESBY, supra note 26, at 119.

323. See id. 
adherence to custom or law, as to the fairest distribution of a contested whale. Scoresby called it the "laws of honour"324 and Melville explained that "upright and honorable whalemen" made allowances in situations where employment of custom would constitute "an outrageous moral injustice" as applied to a worthy party that previously pursued a whale taken by another vessel. ${ }^{325}$

Whalemen in Greenland developed customs that British courts adopted and fit into existing causes of action. Creative British lawyers and courts also looked at whaling disputes and found that desired results could be reached through use of a different cause of action. Whalemen likely never made any real adjustments in their custom to reflect the rulings in Hogarth and Skinner because Scoresby's "laws of honour" were already well established in Greenland ${ }^{326}$ It would be for American courts to establish-or reestablish if seventeenth and eighteenth century practices are considered-the standard of iron holds the whale: pursuit of a detached wounded whale with the prospect of success as sufficient to establish possession. ${ }^{327}$

The creation of British whaling law was neither imposed from above nor crafted, as Ellickson has suggested, exclusively by participants. It was a combination. Whalemen developed a custom that fit well with the existing Roman and common law concepts of how humans developed ownership of wild animals. The men who plied the whaling trade thought about property in the same manner as their contemporaries. They believed Locke's explanation that property rights were created by an application of effort to an object that was not previously owned. ${ }^{328}$ Whaling disputes and the customs and laws established for their resolution were really just arguments about when a whaleman had done enough to earn the right to claim a whale. Competing positions were points on a continuum from lowering boats upon sighting a whale to, at the opposite end, the physical possession of a dead whale. Having created these norms, Greenland whalemen never hesitated to seek resolutions to particular disputes that ignored law and customs, favoring instead mutual agreements that likely were based, in part, on factors such as the history between ships and the group dynamics of numerous vessels sailing in company over the course of months. British courts, in turn, both honored whaling customs and changed the law as part of the ongoing nineteenth century evolution in the available causes of action.

324. Id.

325. MELVILLE, supra note 1 , at 433.

326. See ARCTIC WHALING JouRNALS OF WILliam SCORESBY, supra note 26, at 119.

327. For an American case recognizing the custom of iron holds the whale, see Swift v. Gifford, 23 F. Cas. 558 (1872). For a similar Hawaiian case involving an American and a German ship, see Heppingstone v. Mammen, 2 Haw. 707 (1863).

328. JOHN LOCKE, TWO TREATISES OF GOVERNMENT 219 (1764).

We welcome responses to this Article. If you are interested in submitting a response for our online companion journal, Ecology Law Currents, please contact ecologylawcurrents@ boalt.org. Responses to articles may be viewed at our website, http://www.boalt.org/elq. 